\title{
THE WTO AS A LAW-HARMONIZING INSTITUTION
}

\author{
ARIE REICH*
}

\section{INTRODUCTION}

The violent demonstrations and riots at the ministerial conference of the World Trade Organization ("WTO") 1 in Seattle ${ }^{2}$ have helped draw attention not only to the organization itself (the General Agreement on Tariffs and Trade ["GATT"] and the WTO probably received more publicity during that one week in December 1999 than during its more than fifty odd years of existence), but also to the WTO's potential to serve as a tool for the harmonization of domestic policies in a variety of fields, many of which are only remotely connected to international trade. Since the protesters were made up of a ragbag of different groupsincluding trade unionists, environmentalists, aid lobbyists, consumer-rights campaigners, human-rights activists, and outright anarchists-each group has a different and sometimes

* Dr. Arie Reich; LL.B. (Israel), LL.M., S.J.D. (University of Toronto); Vice Dean, Faculty of Law, Bar Ilan University, Israel. E-Mail: reicha@mail.biu.ac.il. I wish to thank the participants of the 9th Conference of the International Academy of Commercial and Consumer Law, as well as the participants of the Law Faculty Seminar of the Bar Ilan University, where earlier versions of this research were presented and received helpful comments, especially from my colleague Oren Perez.

1 The World Trade Organization ("WTO") was established in 1994 as a multilateral organization aimed at providing a common institutional framework for the conduct of trade relations among its members - that today number about 148 - in matters relating to the agreements and associated legal instruments included in the same 1994 package. The most important of these agreements is the General Agreement on Tariffs and Trade ("GATT"), which in essence originates in an agreement by the same name signed in 1947. Prior to the establishment of the WTO, the institutional framework set up around the GATT and several other side-agreements negotiated under its auspices, served as a semiorganization performing many of the functions that the WTO now performs. See also infra note 13.

2 See Robert Collier, Turmoil in Seattle Streets, S.F. CHRON., Dec. 1, 1999, at A1; The Battle in Seattle, ECONOMIST, Nov. 27, 1999 (U.S. ed.) [hereinafter Battle in Seattle]. 
contradicting agenda. ${ }^{3}$ This observation may not be obvious at first glance, but taken one-by-one it will become more apparent.

The trade unionists, for example, are traditional opponents of trade liberalization, particularly in declining labour-intensive industries that can survive only under the protection of high tariffs or generous subsidies in the face of mounting competition from low-wage developing countries. But they did not take to the streets of Seattle to demand that consumers and taxpayers continue to subsidize their jobs and high wages. Rather, the trade unionists spoke of the need to guarantee higher labour standards in the developing countries-standards more commensurate to those required in the rich and developed countries of the West. Their argument may have taken the form of an altruistic human rights concern, in particular when raising issues such as child labour and subhuman working conditions, but more self-centered concerns about the cost advantage enjoyed by producers in countries with low labour standards lie in the background. This cost advantage may injure both producers and workers in the high-standard country, and thereby also increase opposition to any further rise in those standards. The trade unions of such countries therefore demand that the WTO permit its "Member States" to employ trade restrictions against imports from other Member States whose labour policies do not meet certain basic standards. This would then serve as a means to compel these states to improve their labour standards and to harmonize them with what is accepted in the developed countries - or perhaps with some core standards that are to be set by the WTO or some other international organization (the International Labour Organization ["ILO"], in particular).

The same applies to the environmentalists. Their animosity towards international trade agreements originated in the early nineties when a GATT panel ruled that the United States could not employ trade sanctions in order to impose its own standards of dolphin protection on the rest of the world. ${ }^{4}$ It then gained further steam in connection with the North American Free Trade

3 Battle in Seattle, supra note 2. See W. Russell Mead, World Trade Organization; Skewered in Seattle; In the Suites and on the Streets, Few Agreed, L. A. TIMES, Dec. 5, 1999, at M1.

4 See United States Restrictions on Imports of Tuna, Sept. 3, 1991, GATT B.I.S.D. (39th Supp.) at 155 (1991) [hereinafter United States Restrictions on Imports of Tuna] (stating that a U.S. embargo on certain foreign tuna was an unjustifiable discrimination). 
Agreement ("NAFTA") negotiations, ${ }^{5}$ when they feared that free trade with a country with low environmental standards such as Mexico would lead to a massive flight of U.S. and Canadian industries to south of the Rio Grande, where they would be exempt from the burdensome and expensive environmental regulations of the northern nations. In both cases, the international trade regimes were called upon to facilitate harmonization of environmental standards between the trading nations.

A diametric argument-namely against the harmonizing function of the WTO-was also surprisingly represented among the somewhat peculiar alliance of demonstrators. Behind the catchy slogan "The WTO kills people. Kill the WTO" that appeared on many banners in Seattle, ${ }^{6}$ stands a serious criticism of the standards of intellectual property protection claimed to have been forced upon developing countries by the WTO's Agreement on Trade-Related Aspects of Intellectual Property Rights ("TRIPS Agreement"), concluded in the Uruguay Round of $1994 . .^{7}$ The critics argued that as a result of the agreement the price of essential drugs will skyrocket in many developing countries and become unavailable for a large part of the poor population who needs them most.

Seen from whatever angle, the issue of divergent national standards and rules, and the prospect of harmonizing them in connection with the world's international trade regime, appears to have become a central motif of the WTO.

The central argument of this Article is that the WTO is emerging as a major player in the field of global harmonization of national laws. Usually, when we think of institutions that deal with and promote harmonization of law, we think of organizations such as the International Institute for the Unification of Private Law ("UNIDROIT"), the United Nations Commission on

5 North American Free Trade Agreement, Dec. 17, 1991, 32 I.L.M. 289, 289-605 (1993) [hereinafter NAFTA].

6 Battle in Seattle, supra note 2.

7 Agreement on Trade-Related Aspects of Intellectual Property Rights, Dec. 15, 1993, Marrakesh Agreement Establishing the World Trade Agreement, Annex 1C, 33 I.L.M. 81 (April 1994) [hereinafter TRIPS]. The TRIPS Agreement is further discussed infra Section 3.

8 The International Institute for the Unification of Private Law ("UNIDROIT") is an independent inter-governmental organization with its seat in Rome. Its purpose is to examine ways of harmonizing and coordinating the private law of States and of groups of States, and to gradually prepare for the adoption by States of uniform rules of private law. It was established in 1926 as 
International Trade Law ("UNCITRAL"), 9 or even nongovernmental organizations ("NGOs"), such as the International Chamber of Commerce ("ICC"). ${ }^{10}$ The WTO, in contrast, is usually perceived of as an organization whose mandate is to lower artificial trade barriers between nations - such as custom tariffs, quotas, and other border measures - and not as an organization that attempts to harmonize national policies, such as domestic commercial laws. That perception of the GATT/WTO-as shown in this Article - was basically correct in the past, at the outset of the GATT regime, but it is not accurate anymore.

This Article will examine the harmonizing function of the WTO, first historically, and then prospectively, in an attempt to map the areas of law where potential exists for harmonization within the WTO. This Article will demonstrate that while the GATT regime did not deal with law originally, nor was it very keen to use law as a means to achieve its objectives, it has gradually had to change its focus - not only by embracing law in the latter sense (as has been widely discussed in the literature), ${ }^{11}$ but also by viewing domestic law as part of its subject matter. This Article will show that this shift in perspective opens up wide horizons for new harmonization initiatives that were unthinkable

an auxiliary organ of the League of Nations and later, following the demise of the League, re-established in 1940 on the basis of a multilateral agreement, the UNIDROIT Statute. It has currently 58 Member States. See generally UNIDROIT website, at http://www.unidroit.org (last visited Feb. 26, 2004).

9 United Nations Commission on International Trade Law ("UNCITRAL") is the core legal body within the United Nations system in the field of international trade law. It was established in 1966 by the General Assembly with the mandate to further the progressive harmonization and unification of the law of international trade. Its seat is in Vienna. See UNCITRAL's official website, at http://www.uncitral.org (last visited Feb. 26, 2004).

10 The International Chamber of Commerce ("ICC"), seated in Paris, was founded in 1919 as a worldwide association of merchants and business organizations. Today it groups thousands of member companies and associations from over 130 countries. It has initiated and promoted several sets of uniform rules that govern the conduct of business across borders. Although these rules are voluntary, they have been widely accepted by merchants and banks, and even courts of law, and have become part of the fabric of international trade. See ICC official website, at http://www.iccwbo.org (last visited Feb. 26, 2004).

11 See generally Thomas J. Dillon, Jr., The World Trade Organization: A New Legal Order for World Trade?, $16 \mathrm{MiCH}$. J. INT'L L. 349 (1995) (discussing the innovations and problems of the new dispute resolution and settlement mechanisms of the WTO); Arie Reich, From Diplomacy to Law: The Juridicization of International Trade Relations, 17 Nw. J. INT' L. L. \& Bus. 775 (1996-1997) (discussing how trade relations of GATT members are being adjudicated). 
just a few years ago, both within the GATT and, in many cases, elsewhere, as well. The last part of the Article examines the institutional advantages and disadvantages of an organization, like the WTO, assuming the role of a law-harmonizing institution, in comparison to the bodies that hitherto have been performing this role, and suggests ways in which the WTO could improve its working and negotiating procedures in order to better fulfill its new role.

\section{THE TRADITIONAL NON-HARMONIZING APPROACH OF THE GATT}

Unlike the Treaty Establishing the European Community ("EEC Treaty"),12 the GATT,13 which until today serves as the foundation of the WTO, does not list harmonization of the national laws or domestic policies of its signatories as one of its objectives. In fact, the traditional policy of the multilateral trade regime was to distance itself from anything that would appear as an intervention in the internal affairs of its signatories. Its mandate was to contribute to "the substantial reduction of tariffs and other barriers to trade and to the elimination of discriminatory treatment in international commerce."14

For that purpose, two main types of trade measures were the targets of the GATT: (1) border measures and (2) internal measures that discriminate between domestic and foreign products or between products sold abroad and those sold domestically. Border measures can be divided into tariffs and non-tariff barriers

12 See TREATY ESTABlishing THE EUROPEAN ECONOMIC COMMUNITY, Mar. 25, 1957, art. 3, 298 U.N.T.S. 11, at 47-49 (1957) [hereinafter EEC TREATY], (listing among the activities of the Community, in addition to the elimination of customs duties and quantitative restrictions on the import and export of goods, the establishment of a common commercial policy, a common policy in the sphere of agriculture and fisheries and in the sphere of transport, and "the approximation of the laws of Member States to the extent required for the functioning of the common market.").

13 General Agreement on Tariffs and Trade, Oct. 30, 1947, 55 U.N.T.S. 194 [hereinafter GATT]. The GATT was originally put into effect pursuant to the Protocol of Provisional Application of the GATT, 55 U.N.T.S. 308. Today it is incorporated into the Marrakesh Agreement Establishing the World Trade Organization pursuant to its Article II. See Marrakesh Agreement Establishing the World Trade Organization, Apr. 15, 1994, 33 I.L.M. 1144 (1944) [hereinafter WTO Agreement], reprinted in LEGAL INSTRUMENTS - RESULTS OF THE URUGUAY ROUND VOL. 6 (1994) [hereinafter RESULTS OF THE URUGUAY ROUND].

14 GATT, id. at 196. 
to trade. Tariffs are tolerated as such by GATT, but are subject to multilateral negotiations between the signatories, aimed at reducing them gradually and reciprocally and in accordance with the Most Favored Nation ("MFN") principle.15 Any other border restrictions against imports or exports (other than duties, taxes or other charges), "whether made effective through quotas, import or export licenses or other measures," are in principle prohibited.16 As for internal measures, these are governed by the National Treatment principle, which forbids discrimination between domestic and imported products. ${ }^{17}$ What is common to these two types of prohibited measures is that both serve as artificial barriers to the free flow of international trade and as means of protection for domestic producers, and are usually introduced precisely for those purposes. In other words, they are usually measures of international trade policy, and not domestic policies. ${ }^{18}$ In principle, a GATT signatory is entitled to adopt any domestic policy it finds fit, as long as it applies to both domestic and foreign products alike and does not discriminate against foreign products based on their origin. Hence, at least in the beginning, there were no aspirations to harmonize or approximate national domestic policies-even though the differences in these policies often served in themselves as barriers to the free flow of international trade.

This point is amply illustrated by one of the first cases of the WTO dispute settlement system-United States-Standards for Reformulated and Conventional Gasoline ${ }^{19}-$ which was litigated mainly under provisions originating from the 1947 General Agreement. It was also one of the many cases that prompted criticism from the environmental community, who saw the WTO Panel's ruling, which was aimed against certain provisions of the

15 See id. arts. I (General Most Favored Nation Treatment), XXVIII (Modification of Schedules), and XXVIII (Tariff Negotiations).

16 Id. art. XI:1 (general elimination of quantitative restrictions).

17 Id. art. III (national treatment of internal taxation and regulations).

18 See Frieder Roessler, Diverging Domestic Policies and Multilateral Trade Integration, in 2 FAIR TRADE AND HARMONIZATION: PREREQUISITE FOR FREE TRADE? 21 (J. Bhagwati et al. eds., 1996).

19 WTO Panel Report on the United States-Standards for Reformulated and Conventional Gasoline, WT/DS2/R (Jan. 29, 1996), available at http://www.wto.org/english/tratop_e/dispu_e/dispu_status_e.htm\#1996 (last visited Feb. 16, 2004); WTO Appellate Body Report, United States-Standards for Reformulated and Conventional Gasoline, WT/DS2/AB/R (Apr. 29, 1996) [hereinafter Appellate Report], available at http://www.wto.org/english/ tratop_e/dispu_e/distabase_e.htm (last visited Feb. 26, 2004). 
U.S. Federal Clean Air Act of 1990, as interfering with the United States' domestic environmental policy. In fact, the Panel did not rule against the legitimacy of the Act itself. Nor did it rule against the right of any WTO member to determine its own environmental policies $^{20}$ - even if these are materially different from those of other members and consequently make it harder for other members to export their gasoline to such a member. What the Panel did rule against was the failure of the United States to live up to its obligation under Article III:4 of GATT, to accord to imported gasoline no less favourable treatment than that accorded to like gasoline of U.S. origin. The Panel found that under the implementing rules of the Act, imported gasoline was effectively prevented from benefiting from the same favourable sales conditions as were afforded domestic gasoline, and therefore imported gasoline was treated less favourably than domestic gasoline. While it had been acknowledged in previous panel decisions that in certain cases one may be allowed to treat domestic and imported products formally differently (because of the different circumstances surrounding their entry into the market), the different treatment may not be qualitatively less favourable than that accorded to the domestic product. This was held to mean that products may not be accorded competitive opportunities that are less favourable..21 However, as long as this standard was met, Member States were free to introduce whatever domestic regulations they wished, even if such regulations - because of their peculiarity-might impair the export opportunities of their trading partners. Article III - as it was held in a 1988 panel report-could not be interpreted to protect expectations on export volumes. ${ }^{22}$

This approach is, of course, much different from the one taken by the EEC Treaty and the European Court of Justice. There, even an equally applicable measure may be prohibited by the treaty rules if it effectively causes obstacles to the free movement of goods. Thus, in the famous case of Cassis de Dijon,23 a German law laying down a minimum alcohol level of $25 \%$ for certain spirits - local and

20 See Appellate Report, supra note 19, at 30 (concluding words of the appellate body).

21 United States Section 337 of the Tariff Act of 1930, Nov. 7, 1989, GATT B.I.S.D. (36th Supp.) at 386, para. 5.11 (1990).

22 United States Taxes on Petroleum and Certain Imported Substances, June 17, 1987, GATT B.I.S.D. (34th Supp.) at 158, para. 5.1 .9 (1988).

23 Case 120/78, Rewe-Zentral AG v. Bundesmonopolverwaltung fur Branntwein (hereinafter Cassis de Dijon), 1979 E.C.R. 649. 
foreign alike-could be declared illegal, because it effectively banned French cassis (which traditionally has an alcohol content of 15-20\%) from the German market. Once French cassis enters the German market, it will, as a practical matter, be very difficult for the German authorities to maintain the prohibition against the German production of similar spirits with lower alcohol levels. Thus, the European approach, besides dismantling more barriers to trade, no doubt also has a harmonizing effect on the European Member States that is lacking in the traditional GATT regime.

A similar trend can be found in the GATT approach to subsidies. From a purely economic standpoint, a subsidy granted to a product that is exported to another country will cause the same amount of distortion, as well as hardship for competing producers, regardless of whether the subsidy is conferred upon exportation alone, or upon the plant's entire production. In both cases, the price of the product is not likely to reflect the real competitive advantage of the producer in question, and may therefore distort the market mechanism. Nevertheless, until the Uruguay Round, only export subsidies were prohibited under GATT or under one of its side agreements, while other subsidies were largely tolerated. Thus, under GATT Article XVI, while it is recognized that various types of subsidies may operate to increase exports or to reduce imports, and may thereby cause "serious prejudice" to the interest of any other contracting party, this in itself did not result in any prohibition on such subsidies. ${ }^{24}$ It was only in relation to subsidies on the export of primary products 25 that the Agreement used restrictive language, such as "seek to avoid" (in general) and "shall not" (in relation to subsidies which result in a contracting party having more than an "equitable share" of world export trade in that product). ${ }^{26}$ Even in the more farreaching agreement of the 1979 Tokyo Round, an outright prohibition was only imposed on export subsidies conferred upon industrial products. ${ }^{27}$ And why not upon all subsidies that distort

24 See GATT, supra note 13, art. XVI, para. 1.

25 A "primary product" in this context is defined as "any product of farm, forest or fishery, or any mineral . . . ." See id. art. XVI.

26 See id.

27 See Agreement on Interpretation and Application of Articles VI, XVI and XXIII of the General Agreement on Tariffs and Trade, Sept. 14, 1973, GATT B.I.S.D. (26th Supp.) at 68, art.9 (1979) (this agreement is commonly referred to as the Tokyo Round Subsidies Code). "Export subsidies" are considered as such 
international trade? It was apparently felt that this would be too much of an intrusion into domestic matters. If a contracting party chose to confer subsidies upon an entire domestic industry - both on production for the domestic market as well as for export-this was seen as a matter of internal socio-economic policies with which GATT should not interfere. Thus, GATT did not strive to harmonize the national policies of its signatories even when such policies may have caused considerable distortion of international trade.

\section{GATT'S GRADUAL ASSUMPTION OF THE HARMONIZATION ROLE}

The transformation of the GATT/WTO regime into a system which features not only elimination of artificial trade barriers, but also harmonization of domestic policies, was not a sharp shift that happened overnight, but rather a gradual evolutionary process, which is still only in its initial stages. At first, the harmonization of certain rules and procedures was simply a by-product of the need to eliminate straightforward trade barriers. Gradually, however, the harmonizing measures were deliberately expanded so as to affect pure domestic policies and rules.

\subsection{Antidumping and Countervailing Duties}

Take, for example, GATT's evolving regulation of the way national authorities must administer the imposition of antidumping and countervailing duties. Its origin, in Article VI of the 1947 General Agreement, merely sets out the basic conditions for the contracting parties' right to impose such duties. ${ }^{28}$ One must keep in mind that the imposition of any import duty in excess of a party's bound tariff on a particular product is generally prohibited under GATT. Antidumping countervailing duties are an exception to this rule. It is therefore clear that this exception needs to be carefully restricted in order to prevent its abuse. Indeed, the legalistic producer-induced mechanism of antidumping or countervailing duty proceedings soon became an extremely attractive option for industries threatened by inexpensive imports, and turned into a widely exploited venue for circumventing the general rule

when they are bestowed contingent, in law or in fact, upon export performance.

28 GATT, supra note 13, art. VI. 
prohibiting import duties. ${ }^{29}$ It soon became clear that the GATT basic rules were not sufficient and that more stringent and detailed rules were required. The first step in this direction was taken with the 1967 Antidumping Code, ${ }^{30}$ which set out some minimal procedural standards for antidumping proceedings. The regulation efforts continued with the 1979 Tokyo Round Antidumping Code, ${ }^{31}$ and in the course of the Uruguay Round, the currently prevailing Antidumping Agreement was concluded. ${ }^{32}$ The provisions of these agreements, and in particular of the last one, go into very meticulous details of both the substantive and procedural aspects of antidumping proceedings. The agreement defines what is considered to be dumping, how one should go about computing the various components of the dumping calculations, and what needs to be investigated for the purpose of determining whether or not injury has been caused by the dumping. The almost thirty-page-long agreement also meticulously sets out all the procedural and evidentiary requirements that must be met throughout the proceedings: from the stage of the submission of a complaint on behalf of a domestic industry; through the initiation of an investigation, due process and hearing; until the decision whether or not to impose an antidumping duty. It deals with the provisional measures that may be applied and the conditions that have to be met in order to apply them. It even goes into questions regarding periodical reviews of the cases, as well as to Members' duty to provide judicial review. Almost identical procedural provisions can be found in the countervailing duty section of the Uruguay Round Agreement on Subsidies and Countervailing Measures. ${ }^{33}$

29 See ANTIDUMPING, HOW IT WORKS AND WHO GETS HuRT O. Michael Finger ed., 1993); C.D. HowE INST., FAIR EXCHANGE: REFORMING TRADE REMEDY LAWS (M.J. Trebilcock \& R.C. York eds., 1990).

30 Agreement on Implementation of Article VI of the General Agreement on Tariffs and Trade, May 21, 1963, 651 U.N.T.S. 320, GATT B.I.S.D. (15th Supp.) at 24 (1968).

31 Agreement on Implementation of Article VI of the General Agreement on Tariffs and Trade, GATT B.I.S.D. (26th Supp) at 171 (1980).

32 Agreement on Implementation of Article VI of the General Agreement on Tariffs and Trade 1994 [hereinafter 1994 Antidumping Agreement], reprinted in RESULTS OF THE URUGUAY ROUND, supra note 13 , at 168 , available at http://www.wto.org/english/docs_e/legal_e/19-adp.pdf (last visited Feb. 26, 2004).

33 Agreement on Subsidies and Countervailing Measures Part IV [hereinafter 1994 Subsidies Agreement], reprinted in RESULTS OF THE URUGUAY ROUND, supra note 13, at 264, 273, available at http://www.wto.org/english/docs_e/legal_e/24scm.pdf (last visited Feb. 26, 2004). 
These detailed agreements do not leave very much leeway for national regulation, and as a result, the antidumping and countervailing duty legislation of most WTO members is quite similar. ${ }^{34}$ Of course, a Member State is not required to adopt any such legislation if it chooses not to avail itself of antidumping or countervailing duties. But if it does-and over the past few years more and more states have done $\mathrm{so}^{35}$ - it must ensure that its laws, regulations, and administrative procedures are in conformity with the provisions of the relevant WTO agreements. ${ }^{36}$ Indeed, the many developing countries that have introduced trade remedy laws since the Uruguay Round have all fashioned their laws in accordance with the detailed provisions of these agreements, and in many cases have simply translated them into their own language and adopted them into law. ${ }^{37}$ The harmonizing effect of these WTO instruments is therefore compelling, even though their original objective was not to harmonize but to prevent abuse.

34 This is not to say that the laws of all WTO members in this regard are identical. There are many issues that the WTO agreements have left to the discretion of the Members, such as whether to adopt the "lesser duty rule" and whether to conduct inquiries of "community (or national) interest," to name only a few contentious examples. There are also issues that the agreements have not dealt with, such as anti-circumvention measures and institutional aspects of the investigations and determinations. In relation to these issues and aspects we will, of course, find differences between the various national regimes. In relation to most aspects, however, the legal regimes are very similar.

35 The last few years have seen a sharp rise in the use of antidumping measures, in particular by new users in the developing countries, who in the past did not have any antidumping legislation in place. See Jorge Miranda, et al., The International Use of Antidumping: 1987-1997, 32 J. WORLD TRADE, 5-71 (1998); Antidumping Goes Global, BUS. TODAY (Oct. 30, 1998).

36 See 1994 Antidumping Agreement, supra note 32, art. 18; 1994 Subsidies Agreement, supra note 33, art. 32 .

37 For a detailed survey of the situation in the countries of Central and SouthAmerica, see Organization of American States, Trade Unit, Compendium of Antidumping and Countervailing Duty Laws in the Western Hemisphere (1997), available at http://www.ftaa-alca.org/WGroups/WGADCVD/english/toc.asp. The survey reports that most of the countries of North, Central and South America have incorporated the provisions of these two agreements into their national legislation. Israel has also incorporated whole parts of the agreements (in particular all the provisions on determination of injury) into the bill that is now pending for the amendment of the existing trade remedy law-The Trade Charges Law, 5751-1991. See generally Arie Reich, Institutional and Substantive Reform of the Antidumping Agreement: Lessons from the Israeli Experience, J. WORLD TRADE, Dec. 2003. 


\subsection{Customs Administration}

The same pattern can be found in relation to the entire regime of customs administration. While GATT started off concentrating mainly on the rates of customs, it soon had to devote more attention and energy to the way customs are administered and assessed, as well as to other formalities and fees connected with importation and exportation. In addition to the basic provisions of the GATT in this regard, ${ }^{38}$ we now have several additional agreements within the WTO regime that deal with these issues in detail and which have the cumulative effect of harmonizing the customs and importation laws of all WTO members. ${ }^{39}$ The frequent tariff negotiations between GATT/WTO members, and the need to provide statistical data on trade flows that is comparable between these members were also instrumental in promoting another important harmonization project-the Harmonized Commodity Description and Coding System ("Harmonized System")-developed by the Custom Cooperation Council ("CCC") in 1983.40 Over time all major GATT members have made this uniform system the basis of their customs classification systems.

A further step towards harmonization in this field was taken with the Uruguay Round Agreement on Rules of Origin. ${ }^{41}$ One of the express objectives of this agreement is to harmonize the rules of origin used by all WTO members in connection with imports

38 See GATT, supra note 13, arts. VII, VIII.

39 In particular: the Custom Valuation Agreement [formally known as the Agreement on Implementation of Article VII of the General Agreement on Tariffs and Trade 1994], reprinted in RESULTS OF THE URUGUAY ROUND, supra note 13, at 197, available at http://www.wto.org/english/docs_e/legal_e/20-val.pdf; Agreement on Preshipment Inspection, reprinted in RESULTS OF THE URUGUAY ROUND, supra note 13, at 230, available at http://www.wto.org/english/ docs_e/legal_e/21-psi.pdf (last visited Feb. 26, 2004); Agreement on Import Licensing Procedures, reprinted in RESULTS OF THE URUGUAY ROUND, supra note 13, at 255, available at http://www.wto.org/english/ docs_e/legal_e/23-lics.pdf (last visited Feb. 26, 2004).

40 International Convention on the Harmonized Commodity Description and Coding System, June 14, 1983, 1035 U.N.T.S. 3.

41 Agreement on Rules of Origin, reprinted in RESULTS OF THE URUGUAY RouND, supra note 13, at 241, available at http://www.wto.org/english/docs_e/ legal_e/22-roo.pdf (last visited Feb. 26, 2004). "Rules of origin" are the criteria used to define where a product was made. They are an essential part of trade rules and import administration because a number of policies discriminate between exporting countries: Most Favored Nation ("MFN") tariffs (not always granted to non-members of the WTO), quotas, preferential tariffs, antidumping actions, countervailing duties, government procurement, and more. 
coming under the WTO agreements. ${ }^{42}$ Until now, countries have used different rules with different criteria to determine the origin of certain goods, leading sometimes to severe problems of incompatibility as well as the use of the rules as disguised barriers to international trade. ${ }^{43}$ For this purpose, the agreement establishes a set of guiding principles that are to serve as the basis for a work program that is to be undertaken by the WTO's Ministerial Conference in conjunction with the CCC. The work, scheduled to be completed by July 1998, turned out to be more complicated than anticipated, and required several time extensions. Nevertheless, it appears that it has by now been largely completed except for a few outstanding issues. ${ }^{44}$

Needless to say, the harmonizing effect in this and other fields is increasing significantly as the number of members of the GATT/WTO system rises steadily over time, and in particular because many of the previously voluntary side agreements have become mandatory as a result of the Uruguay Round. 45

\subsection{Government Procurement Law}

Another agreement within the GATT/WTO framework that has had an important harmonizing effect on its signatories' laws and procedures is the Agreement on Government Procurement ("AGP").46 This agreement, which was first promulgated in the course of the Tokyo Round that ended in 1979, and later by a more extensive agreement following the Uruguay Round in 1994, deals

42 See id. (seeking to harmonize and clarify rules of origin).

43 See, e.g., Norio Komuro, International Harmonization of Rules of Origin, in THE WTO AND INTERNATIONAL TRADE REGULATION 86 (P. Rutley et al. eds., 1998).

44 Press Brief, WTO, Rules of Origin, at http://www.wto.org/english/ thewto_e/minist_e/min96_e/rules.htm (last visited Jan. 31, 2003).

45 The "Custom Valuation Code," for instance, was already in existence after the Tokyo Round, but had only some twenty signatories at the time. See GATT Secretariat, The Texts of Tokyo Round Agreements, GATT/1986-5 (1986) [hereinafter Tokyo Round]. Following the Uruguay Round, this agreement became part of the "single undertaking" and thereby binds all current WTO members. See Custom Valuation Agreement, supra note 39.

46 Agreement on Government Procurement, Tokyo Round, supra note 45, at 27. For the Agreement on Government Procurement that was reached in the Uruguay Round that superceded the prior agreement, see Agreement on Government Procurement, Apr. 15, 1994, Marrakesh Agreement Establishing the World Trade Organization, Annex 4 [hereinafter Uruguay Round AGP], reprinted in RESULTS OF THE URUGUAY ROUND, supra note 13, at 438, available at http://www.wto.org/eng lish/tratop_e/gproc_e/agrmnt_e.htm (last visited Feb. 26, 2004). 
with laws, regulations, procedures, and practices of government purchasing. ${ }^{47}$ Again, the objective of the AGP is not to harmonize this important field of law, but rather to liberalize and expand trade in the public sector by eliminating preferential treatment of domestic suppliers and products and ensuring fair and open international competition for government contracts. However, it was soon realized that this objective could not be achieved solely by prohibiting discrimination. What was needed was a detailed procedural regime that would prescribe rules on tendering procedures and contract award criteria. The AGP therefore adopted such a regime, which in its content strongly resembled what you would expect to find in any national legislation regulating government tendering and contracting. It includes detailed rules on how government tenders must be conducted, how and where they should be advertised, how qualification of suppliers should be conducted, how to use technical specifications, and how to conduct selection procedures. It prescribes minimum time limits for tendering and delivery; as well as the information that must be contained in the tender documentation; and lays down rules on how the submission, receipt and opening of tenders should be conducted; and how the awarding of contracts should be made. It even requires its parties to provide judicial or quasi-judicial challenge procedures whereby an aggrieved supplier can bring a complaint against a procuring agency in case of breach of any of the AGP provision and prescribes certain standards that such procedures must meet. ${ }^{48}$

The AGP has clearly had a harmonizing effect on the government procurement law of its signatories (which do not include all the members of the WTO). ${ }^{49}$ They have had to amend their laws and regulations in this field to conform to the AGP provisions.50 Many of them have also had to set up specialized administrative tribunals to hear bid protests and challenges or to amend their laws so as to allow judicial review by their regular

47 For an extensive discussion of these agreements, see ARIE REICH, International Public Procurement LaW: The Evolution of International Regimes on Public Purchasing 103-140, 279-318 (1999).

48 See Uruguay Round AGP, supra note 46 , at art. XX.

49 The AGP has the status of a "plurilateral" agreement, and is not a part of the "single undertaking," which binds all the current 148 members of the WTO. The parties to the AGP are mainly developed industrialized countries, such as the United States, Canada, Japan, the European Union Member States, and other Western European countries, all in all, twenty or so states.

50 See Uruguay Round AGP, supra note 46, art. XXIV. 
courts. Consequently, as of today, the law of government tendering and contracting in AGP countries is much more uniform than it would have been in the absence of the AGP.

In the existing literature on the AGP, this aspect has gone almost unnoticed. The reason is that harmonization, as we noted earlier, was never an official objective of the agreement. It is, however, a byproduct with many blessings. In addition to compelling many states to introduce clear, transparent, and truly competitive rules of tendering that prevent not only domestic protectionism, but also corrupt favouritism, the greater uniformity between the national systems also makes it easier for suppliers to participate in the market for foreign government contracts.

Evidence of the AGP's harmonizing function can be found if we compare it to the parallel liberalization instruments of the European Community ("EC"). These instruments, the public procurement directives that were adopted first in the seventies and then later as part of the "Europe 1992" program,51 served as a model for the AGP, both in the Tokyo Round and in the Uruguay Round.52 Hence, both the structure and contents of the AGP are very similar to those found in these instruments. However, the harmonizing function in the AGP is concealed, while it is explicit

51 The first coordination directive was Council Directive 71/305 of July 26, 1971, 1971 O.J. (L 185) 5 (relating to the coordination of procedures for the award of public works contracts). It was followed by Council Directive 77/62 of December 21, 1976, 1977 O.J. (L 13) 1 (coordinating procedures for the award of public supply contracts). These two directives were amended and considerably strengthened in the late eighties. See Council Directive 88/295, 1988 O.J. (L 127) 1 (amending Directive 77/62 in March 1988, relating to the coordination of procedures on the award of public supply contracts and repealing certain provisions of Directive 80/767); Council Directive 89/440, 1989 O.J. (L 210) 1 (amending Directive 71/305 in July 1989, concerning coordination of procedures for the award of public works contracts. Then additional directives were imposed the tendering regime also on entities operating in the water, energy, transport and telecommunication sectors (so-called public utilities). See Council Directive 90/531 [hereinafter Council Directive 90/531], 1990 O.J. (L 297) 1 (concerning the procurement procedures of entities operating in the water, energy, transport and telecommunications sectors); Council Directive 92/50, 1992 O.J. (L 209) 1 (relating to the coordination of procedures for the award of public service contracts).

52 See ReICH, supra note 47, at 109, 279; Morton Pomeranz, Toward a New International Order in Government Procurement, 11 LAW \& POL'Y INT'L Bus. 1263, 1263-1300 (1979) (tracing the remarkable policy developments represented by the AGP); Gerard de Graaf \& Matthew King, Toward a More Global Government Procurement Market: The Expansion of the GATT Government Procurement Agreement in the Context of the Uruguay Round, 29 INT'L LAW. 435, 435-452 (1995) (discussing the importance of European Community measures in influencing subsequent agreements, namely the AGP). 
in the EC directives. The directives are adopted with the objective of "coordinating" the procedures for the award of public contracts (not just to "liberalize and expand trade in the public sector"). Also among the authorizing provisions of the EEC Treaty referred to in the preambles are provisions whose express objective is "the approximation of laws" and "the achievement of uniformity." 53 Given the similarity of the AGP to the directives, it is clear that it too serves to achieve approximation of laws and greater uniformity among its parties.

\subsection{Sanitary and Phytosanitary Measures}

One Uruguay Round Agreement that expressly mentions harmonization as one of its objectives is the Agreement on the Application of Sanitary and Phytosanitary Measures (the "SPS Agreement"). ${ }^{54}$ This agreement deals with measures adopted by Member States in order to protect human, animal, plant life, and health from risks of plant- or animal-borne pests or diseases and to ensure food safety in general. Historically, the GATT had recognized the right of contracting parties to take measures necessary to protect human, animal, and plant life or health, even if such measures impose trade restrictions. GATT Article XX(b) provides a general exception for measures of this kind from the obligations imposed by GATT-provided that such measures are not applied in a manner that would constitute arbitrary or unjustifiable discrimination between countries or a disguised restriction on international trade. Thus, the issue was seen as a domestic policy matter, subject to the prohibition on discrimination (both in relation to domestic products and suppliers, as well as to

53 The early coordination directives both refer to Article 100 of the EEC Treaty, which is found in Chapter 3 of Title V of the Treaty, titled "Approximation of Laws." EEC TREATY, supra note 12. It provides for the issuing of directives "for the approximation of such provisions laid down by law, regulation or administrative action in Member States as directly affect the establishment or functioning of the common market." Id. at 54. The later public utilities directive, Council Directive 90/531, refers to (the then existing) Article 100a, found in the same chapter and with a wording similar to Article 100. See Council Directive 90/531, supra note 51 . It also refers to Article 113, which deals with the common commercial policy and talks about "uniform principles" and "the achievement of uniformity in measures of liberalization." Id.

54 Agreement on the Application of Sanitary and Phytosanitary Measures [hereinafter SPS Agreement], reprinted in RESULTS OF THE URUCUAY ROUND, supra note 13, at 69 , available at http://www.wto.org/english/docs_e/legal_e/15sps.pdf (last visited Feb. 26, 2004). 
those of other contracting parties), and there was no attempt to harmonize national safety standards.

The SPS Agreement takes a different approach. It declares in its preamble that the Members desire "to further the use of harmonized sanitary and phytosanitary measures between Members." 55 This should be done on the basis of international standards, guidelines, and recommendations developed by the relevant international organizations, such as the Codex Alimentarius Commission, 56 the International Office of Epizootics,57 and others. Article III of the Agreement, under the heading "Harmonization," requires Member States to base their SPS measures on international standards, guidelines, or recommendations, where they exist, in order to harmonize such measures "on as wide a basis as possible." 58 National SPS measures that conform to such international standards shall be deemed to be GATT consistent, while states that require higher levels of protection must be able to justify them scientifically in order to be GATT consistent. ${ }^{59}$ Considering the heavy burden often involved in such scientific justification, WTO Member States have strong incentives to adopt existing international (uniform) standards in order to stay clear of legal challenges. The rationale for this approach stems probably from the realization that the diversity in standards itself poses a trade barrier, in addition to its potential of serving as a hard-to-detect disguise for national protectionist

55 Id. (emphasis added).

56 The Codex Alimentarius Commission was created in 1963 by the UN Food and Agriculture Organization ("FAO") and the World Health Organization ("WHO") to develop food standards, guidelines, and related texts such as codes of practice. See Codex Alimentarius Commission, FAONHO Food Standards, at http://www.codexalimentarius.net/index_en.stm (last visited Feb. 26,2004)

57 The International Office of Epizootics ("OIE") is an intergovernmental organization devoted to animal health and created by the International Agreement of Jan. 25, 1924. Today it has over 160 Member States. One of its tasks is to develop standards and sanitary rules for animal health. The main normative works produced by the OIE are the International Animal Health Code, the Manual of Standards for Diagnostic Tests and Vaccines, the International Aquatic Animal Health Code, and the Diagnostic Manual for Aquatic Animal Diseases, at http:// www.oie.int/eng/OIE/en_oie.htm (last visited Feb. 26, 2004).

58 This obligation is subject to any exception expressly provided for in the SPS Agreement, and in particular in paragraph 3 (the introduction of a higher level of sanitary or phytosanitary protection - in which case such level must be scientifically justified). See SP Agreement, supra note 54, at 71.

59 Id. As an alternative to scientific justification, Member States can base their higher standards on risk assessment techniques "developed by the relevant international organizations." See id. at 72. 
measures.60 Again, starting from the premise of the need to eliminate trade barriers, we can see how the GATT/WTO regime has evolved from a non-interventionist approach, utilizing traditional trade-law doctrines of MFN and National Treatment (non-discrimination), to an approach clearly promoting harmonization.

\subsection{Intellectual Property Rights}

To conclude our brief survey of GATT's gradual assumption of the harmonization function, we now come to the instrument which probably more than any other epitomizes this development-the TRIPS Agreement. ${ }^{61}$ This agreement, concluded as part of the Uruguay Round, could not be considered as dealing with the elimination of international trade barriers-at least not in the traditional sense. Its subject matter is not international trade measures, but rather domestic laws and policies, most of which apply equally to both domestic and foreign players. ${ }^{62}$ Those policies in the field of intellectual property must, under the TRIPS Agreement, comply with certain minimum standards of legal protection, ${ }^{63}$ which are prescribed by it, and all WTO members whose domestic legal systems do not yet provide such protection are required to amend their laws accordingly. ${ }^{64}$ Those "minimum" standards are in fact more than minimal, and tend to reflect the level of intellectual property protection prevailing in the industrialized countries (but in few developing countries) and mandated by

60 Governments have at times imposed trade restrictions, in the guise of $S \& P$ measures, in order to protect a domestic industry. For example, a country may prohibit imports of a particular agricultural product in order to protect domestic producers of that product, citing an unfounded risk of pest or disease .... Experience has shown that unjustified S\&P measures are frequently employed when other barriers to trade, such as tariffs and non-tariff import restrictions are reduced or removed.

H.R. Doc. No. 103-316, at 742-63 (1994).

61 See TRIPS, supra note 7.

62 There are few exceptions to this characterization. For instance, Article 31 of the TRIPS Agreement, which regulates Member States' use of compulsory licensing, and the National Treatment and MFN Treatment required by Articles 3 and 4 , respectively. See TRIPS, supra note 7 , arts. 3, 4, 31. However, these are not the most significant provisions of the TRIPS Agreement.

63 See TRIPS, supra note 7, arts. 2, 9, 10, 35 (discussing the various intellectual property rights and protections that may be conferred by Member States).

64 See TRIPS, supra note 7, art. 1., para. 1 (requiring Members to implement the provisions of TRIPS). 
leading international treaties. The standards relate both to the availability, scope, and use of intellectual property rights, as well as to the means of their enforcement. In fact, at least one of those treaties - the Berne Convention for the Protection of Literary and Artistic Works - expressly states its objective to achieve as much uniformity as possible among its signatories for the protection of intellectual property. ${ }^{65}$ Hence, the TRIPS Agreement is in effect harmonizing previously divergent national laws in a central field of commercial law - the law of intellectual property.

Nevertheless, the aim of "harmonization" cannot be found in the official objectives of the TRIPS Agreement, as declared in its preamble. Instead, it addresses the need to "reduce distortions and impediments" to international trade, in a rather unconvincing attempt to justify the connection between an intellectual property treaty and a framework devoted to international trade liberalization. The same applies to the insertion of the words "Trade-Related Aspects" in the title of the agreement. It is not a very convincing attempt to justify the connection, given that the core of the TRIPS Agreement is the adoption of standards from existing intellectual property treaties that until recently were not at all considered to be "trade-related." It should be seen as part of the traditional attempt of the GATT regime to distance itself from intervention in the domestic policies of its signatories, and to deal only with international trade measures.

This is not to say that the TRIPS Agreement has nothing to do with international trade. No doubt, in a world of growing trade and increasing interdependence, divergent levels of protection for intellectual property may create uneven playing grounds and distortions to international trade. Industries in a country with a low level of protection can exploit inventions and creations originating in countries with a high level of protection and thus deprive those countries of export opportunities. However, that is not a direct connection, but rather an indirect one, and in any case domestic inventors and creators in the low-level country are also affected to the same extent by the lack of protection. Furthermore, unlike plain trade liberalization, which "the neo-classical theory of trade suggests will, with certain defined exceptions, be always beneficial, both to the domestic economic welfare of the liberalizing state, and to global

65 See Berne Convention for the Protection of Literary and Artistic Works, July 24, 1971, 828 U.N.T.S. 221, pmbl. (amended Sept. 28, 1979). 
economic welfare,"66 the TRIPS Agreement does not necessarily benefit countries that are net importers of intellectual property, such as the developing countries. ${ }^{67}$ For many of them it can therefore be justified only as part of a broader bargain with some other trade-off that is in their interest. What is more important: this is not a phenomenon that is peculiar to intellectual property protection. There are a myriad of areas of domestic policy where divergent national policies and, in particular, divergent levels of legal protection for different players, may distort the "level playing field" and cause "impediments to international trade." Hence, once the WTO has taken upon itself the task of "leveling playing fields" and harmonizing conditions of competition, the potential agenda for future initiatives is almost boundless.

In the Sections that follow, I will try to suggest some potential initiatives that would seem most likely to be brought up within the WTO, while discussing the pros and cons of such proposals and their chances of being adopted. Having done so, one also must ask oneself whether the WTO is the most suitable institution to deal with the harmonization of law. What are the implications of the WTO acting as a law-harmonizing institution in comparison to the international bodies that hitherto have been involved in this task? These are some of the questions that will be discussed in the last Section of this paper.

\section{POTENTIAL FUTURE HARMONIZATION INITIATIVES FOR THE WORLD TRADE ORGANIZATION}

As has been shown above, harmonization has already become part and parcel of the existing GATT/WTO regime. But even more so, it seems to have become a central source of contention in the public debate surrounding the WTO's future agenda. In the Section that follows, I will discuss some of the areas where the WTO could potentially contribute to the harmonization of certain domestic policies in the future.

In the first part of the Section, I will discuss initiatives that

66 Michael J. TRebilcock \& Robert Howse, THE Regulation of INTERNATIONAL TRADE 253 (1995).

67 See A.V. Deardorff, Should Patent Protection Be Extended to All Developing Countries?, 13 WORLD ECON. 497 (1990); Evelyn Su, The Winners and the Losers: The Agreement on Trade-Related Aspects of Intellectual Property Rights and Its Effects on Developing Countries, 23 Hous. J. INT'L L. 169 (2000) (discussing the possible detrimental and beneficial effects of the TRIPS Agreement). 
have already been included in the Doha Development Agenda - the agreed mandate for a new round of multilateral trade negotiations launched by the Ministerial Declaration adopted in Doha, Qatar, on November 14, 2001.68 I will examine briefly the history of these initiatives, the various alternatives open to the negotiators, their harmonization aspects, and the likely outcome of the negotiations in these fields. In the second part, I will discuss some other possible initiatives that have not been included in the Doha mandate, but which may very well be suggested for other future rounds.

\subsection{Initiatives Already Proposed for the Doha Development Agenda}

\subsubsection{Harmonization of Government Procurement Law and Procedures}

The harmonization of government procurement procedures has been discussed in Section 3 above in the context of projects that have already been dealt with by the GATT/WTO regime in previous rounds. It is, however, an important item also on the agenda for a new round. The objective is to try to reach an agreement on government procurement procedures that will be a part of the single undertaking of the WTO, and hence bind all of the 148 current members of the organization, not just some twenty or so countries that currently are parties to the existing plurilateral AGP and most of which are highly developed. The Singapore Ministerial Conference convened in December 1996 set the path to such an achievement. There, it was agreed to establish a working group "to conduct a study on transparency in government procurement practices, taking into account national policies, and, based on this study, to develop elements for inclusion in an appropriate agreement." 69 In Doha, it was formally agreed that negotiations on a multilateral agreement on transparency in government procurement will take place after the Fifth Session of the Ministerial Conference (that subsequently took place in Cancún,

68 WTO Ministerial Conference, 4th Sess., Ministerial Declaration, WT/MIN(01)/DEC/1 (Nov. 14, 2001) [hereinafter Doha Declaration], available at http://www.wto.org/english/thewto_e/minist_e/min01_e/mindecl_e.htm.

69 WTO Ministerial Conference, Ministerial Declaration, para. 21 (Dec. 13, 1996) [hereinafter Singapore Declaration], quoted in WTO Working Group Report on Transparency in Government Procurement to the General Council, WT/WGTGP/1, para. 1 (Nov. 19, 1997), available at http:/ / www.wto.org/ english/tratop_e/gproc_e/gptran_e.htm (last visited Feb. 26, 2004). 
Mexico in September 2003) on the basis of a decision to be taken, by explicit consensus, at that session on modalities of negotiations. ${ }^{70}$ These negotiations will build on the progress made in the Working Group on Transparency in Government Procurement by that time. ${ }^{71}$ The idea behind the new initiative is to tolerate, at least for now, existing price preferences and other explicit discriminatory policies in favour of domestic suppliers, as long as basic standards of transparency and competitive conditions are met. $^{72}$

The harmonizing function of such an agreement would become a much more central component than is the case with the AGP. There are two reasons for this. Firstly, the fact that the new agreement may become binding on a much larger group of states, and, in particular, on developing countries that often lack any regulation of government procurement, will significantly enhance its harmonizing effect. Secondly, unlike the AGP, in which the central objective was to get rid of trade barriers in the public sector (in the form of protectionist procurement policies), the proposed agreement does not prohibit such policies. Rather, it seeks to achieve transparency in the procuring activities of all governments by imposing on them certain basic standards of transparent tendering procedures. A certain amount of harmonization is at the core of this objective.

The emerging components of a possible agreement include provisions on issues such as: (1) transparent information on national procurement rules; (2) rules on where and how to publish invitations to tender; (3) which information is to be included in such

70 There has been some disagreement among Member States on the precise meaning of this formulation. Some Members see it as an outright agreement to open negotiations on this issue, while others stress the need for another decision taken by explicit consensus of all Members, for the negotiations to open. According to the latter reading, the negotiations have not yet been launched, and thus it is still not clear that government procurement will be included in the Doha Round. The same applies to the other three Singapore issues-competition, investment, and trade facilitation.

71 See Doha Declaration, supra note 68, para. 26 ("These negotiations will build on the progress made in the Working Group on Transparency in Government Procurement....").

72 See id. ("Negotiations shall be limited to the transparency aspects and therefore will not restrict the scope for countries to give preferences to domestic supplies and suppliers."). While the issue of "competitive conditions" is not expressly mentioned in the Doha Declaration, it would seem to stem naturally from the prescription of transparent tendering procedures. 
invitations; (4) rules on time tables for the procurement; (5) rules on how to manage closed lists of qualified suppliers; (6) rules on qualification procedures and bid documentation; (7) a requirement for transparency of decisions on qualification; (8) rules on contract award procedures and criteria and on post-award information; (9) and a requirement to maintain fair and transparent judicial, arbitral, or administrative review procedures. ${ }^{73}$ As is usually the case with GATT/WTO agreements in "new" areas, the initial agreement would later be developed and expanded in subsequent negotiation rounds.

\subsubsection{Harmonization of Competition Law}

The connection between competition law (or antitrust law, as it is known in the United States) and international trade has always been quite obvious. There are several ways in which anticompetitive behavior by private firms can affect trade and even prevent entrance by foreign firms. For instance, a firm can engage in monopolization both inside and outside the national borders of its domicile. A number of firms in one or more Member States may set up a cartel in order to raise their export prices to other Member States, thus exploiting the consumers in those states, or they can agree to divide geographical markets in order to eliminate competition between them. In some cases, such anticompetitive behavior receives active support by host governments. In other cases, they can exist due to a lack of regulation or enforcement. Indeed, as traditional government barriers to trade have been reduced, there have been increasing concerns that the gains from such liberalization may be thwarted by private anticompetitive practices. It is probably with this concern in mind that the Treaty of Rome from the outset included rules on competition in order to ensure that competition in the European Common Market is not

73 These components are taken from a proposed draft agreement submitted by Singapore, Korea, Hungary, and the United States in preparation for the Seattle Ministerial of December 1999. See WTO Working Group on Transparency in Government Procurement, Preparations for the 1999 Ministerial Conference, The WTO's Contribution to Transparency in Government Procurement, WT/WGTGP/W/27 (Nov. 9, 1999) (listing elements of a possible agreement). They are also included as items on the agenda item of the Working Group on Transparency in Government Procurement. See WTO Working Group Report on Transparency in Government Procurement to the General Council, WT/WGTGP/6 (Nov. 29, 2002) (listing items on the agenda of the working group in its 2002 annual report). 
distorted. ${ }^{74}$ But not only the Treaty of Rome, which of course goes far beyond what any conventional trade agreement would seek to achieve, included such provisions. They have also been included in all the free trade agreements concluded by the EC with its associated trading partners,75 as well as in other international trade agreements. ${ }^{76}$

GATT, in contrast, does not include any similar provisions and does not yet deal systematically with the trade-competition relationship. This deficiency was amply illustrated in the Kodak-Fuji case, where a U.S. complaint against the alleged anticompetitive nature of Japan's distribution channels for photographic film was entirely rejected, largely because of lack of proper legal basis in the provisions of GATT. ${ }^{77}$ At the Singapore Ministerial Conference in 1996, it was decided to establish a Working Group on the Interaction between Trade and Competition. ${ }^{78}$ The Doha Declaration talks about a "multilateral framework to enhance the contribution of competition policy to international trade," and here too it was agreed that negotiations will start after the next Ministerial Conference based on a consensus decision on the modalities. ${ }^{79}$ The Working Group has been directed to focus on the clarification of core principles, including transparency, nondiscrimination and procedural fairness, provisions on hardcore cartels, modalities for voluntary cooperation, and support for progressive reinforcement of competition institutions in developing countries through capacity building.

The work in this area is only in its initial stages, and it is not yet clear what type of agreement can and should be reached. What is clear, however, is that out of the 148 current WTO members, only

74 ECC TREATY, supra note 12, arts. 85-86 (now arts. 81-82).

75 See, e.g., Agreement Between the State of Israel and the European Economic Community, May 20, 1975, EC-Isr., art. 12, 1975 O.J. (L 136) 5 (including rules on competition in the agreement between the $\mathrm{EC}$ and Israel); see also EuroMediterranean Agreement Establishing an Association Between the European Communities and Their Member States, of the One Part, and the State of Israel, of the Other Part, Nov. 20, 1995, EC-Isr., art. 36, 2000 O.J. (L 147) 3, 10 (finding trade agreements restricting trade as incompatible with the current agreement).

76 For an example of such agreements, see Article 4 of the 1988 Protocol Between Australia and New Zealand, infra note 83.

77 See WTO Panel Report on Japan-Measures Affecting Consumer Photographic Film and Paper, WT/DS44/R (Mar. 31, 1998) (rejecting the U.S. complaint for lack of legal basis in its anti-competition claims against Japan).

78 See Singapore Declaration, supra note 69, at para. 21.

79 See Doha Declaration, supra note 68, para. 23; see also caveat supra note 70. 
about eighty have adopted some kind of competition laws. ${ }^{80}$ That means that over sixty states have no competition laws at all, and have therefore no legal means to prevent anticompetitive practices. Among those who have them, there are certainly varying degrees of enforcement. The Doha Declaration therefore puts much emphasis on enhanced technical assistance and capacity building for the developing and least developed countries. ${ }^{81}$

One approach to combating anticompetitive practices that impede trade - although admittedly a maximalist approach - would be to adopt an agreement that sets comprehensive standards of competition law, which would have to be adopted and enforced by all parties. A more realistic approach would be to concentrate only on some core principles, with standards that could be agreed on by all. Such an agreement would probably, first and foremost, prohibit the exemption of export cartels from national competition law. These exemptions can be found in many WTO members, including the United States and Japan, and they, in essence, permit firms to exploit consumers as long as they are residents of other countries. ${ }^{82}$ But in order to be effective and equally applicable, it would also have to require states that lack any kind of competition law to adopt a prohibition at least on such cartels (if not on all domestic cartels), and then also require proper enforcement of such a prohibition. Then, in order to deal with domestic practices that prevent entry of foreign competitors - such as those alleged to have existed in the

80 See WTO Working Group Report on the Interaction Between Trade and Competition Policy to the General Council, WT/WGTCP/2 (Dec. 8, 1998) (discussing WTO members who have adopted competition laws).

81 See Doha Declaration, supra note 68, para. 24 (recognizing the need for enhanced technical assistance and capacity building for the least developed countries).

82 In the United States, such exemptions are granted under the WebbPomerene Act, 15 U.S.C. \$§ 61-65 (1997), as well as under the Export Trading Company Act of 1982, Pub. L. No. 97-290, 96 Stat. 1233 (1982). See Foreign Trade Antitrust Improvement Act, 15 U.S.C. \$ 6a (1995). In Japan, exemptions are made possible under the Transactions Law. In the EC, exemptions may fall outside the scope of the ECC Treaty's competition rules, which apply only to practices "which may affect trade between the Member States" and which may distort competition "within the common market." See Brian Hindley, Competition Law and the WTO: Alternative Structures for Agreement, in FAIR TRADE AND HARMONIZATION, supra note 18 , at 333-34 (discussing exemptions from national competition laws). In Israel, an export cartel can also be granted an exemption under Article 10(7) of the Restrictive Trade Practices Law, 1988, 42 L.S.I. 135, (1987-1988). Additional support for this assessment can be found in the Doha Declaration, which talks about "provisions on hardcore cartels." See supra note 68 and accompanying text. 
Kodak-Fuji case - the agreement would have to go into more detailed rules of competition, such as those adopted, for example, in the free trade agreements of the EC. Theoretically, a state could implement such obligations in relation to trade-related anti-competitive practices without having to adopt or change any rules in relation to such practices that only affect its domestic players. But once rules and enforcement mechanisms are in place, it would seem quite senseless to employ them only in defense of foreign firms or foreign consumers, pursuant to an international agreement, and not in defense of its own consumers and firms. It would seem more likely that once the national regulator's attention has been drawn to the problem of anticompetitive behavior and the need to draw up regulation and set up enforcement agencies, a more comprehensive approach would be taken towards the need to regulate competitive behavior throughout the market. In doing so, the WTO again is likely to have a significant harmonizing effect on the evolution of national competition laws, even if it is only an indirect effect.

Finally, a future agreement on trade-related competition law may attempt to regulate the phenomenon of transborder predatory pricing. This refers to a situation where a firm from one state attempts to get rid of a competing firm in another state by bringing down its prices to below-cost of production, often cross-subsidizing them through overpriced sales in a protected home market. Presently, competition authorities in the country of the targeted firm often find it hard to confront such behavior through the means of their national competition laws, because of restrictions on its territorial jurisdiction. Instead the country introduces antidumping legislation, which - at least officially - is designed to combat such predatory practices. In practice, such legislation is often used as a pretext for sheer protectionist measures. If - as so many economists have argued - an international agreement on competition law could be adopted that would allow effective cooperation between the competition authorities of its parties, it would make it possible to deal with allegations of predatory practices within the confines of competition law, instead of antidumping law. In such a setting one could then get rid of antidumping procedures altogether. While this is quite a utopian vision, given the strong political pressures that have created and maintained antidumping proceedings for almost a century now, it is still an idea to keep in mind, and one that has even 
been adopted at least in one regional trade agreement. ${ }^{83}$

\subsubsection{Harmonization of Environmental Regulations}

The issue of environmental standards is outside the scope of this Article. ${ }^{84}$ Suffice it to say that the many problems that have surfaced in the last two decades as a result of the differences in the prevailing levels of environmental regulation in different countries could be alleviated if an agreement could be reached on common minimum standards. As in the case of SPS and TRIPS, the WTO would hardly be in a position to set those standards by itself, but would have to refer to existing multilateral environmental agreements or standards. A first step in that direction was taken already by the first Tuna-Dolphin panel, which rejected the U.S. attempt to rely on some of the Article XX environmental exceptions because, inter alia, it had not demonstrated to the Panel "that it had exhausted all

83 In Article 4 of the 1988 Protocol between Australia and New Zealand, pursuant to the Australian-New Zealand Closer Economic Relations Trade Agreement og 1998, Austl. T.S. No. 18, both countries agreed that as of 1990 all antidumping actions between the two countries should cease and that any antidumping duties then in place should be terminated. In place, harmonized provisions of both countries' competition laws pertaining to abuse of dominant position have been substituted. These provisions permit a complainant located in one country to complain of abusive behavior by a firm or firms located in the other country. The courts in the first country are then authorized to hold hearings in the second country and to use the second country's courts to enforce subpoenas and other orders. See TREBILCOCK \& HOWSE, supra note 66, at 123. The fact is that antidumping actions have been abolished as between the Member States of the European Community ("EC"), at least partly based on the common competition rules that now prevail and the fact that there is a supra-national enforcement agency, namely the European Commission.

84 The last decade has seen an outburst of academic writing on this topic in connection with the GATT and the World Trade Organization. See, e.g., THE GREENING OF WORLD TRADE IsSUES (Kym Anderson et al. eds., 1992) (providing a compilation of papers concerning trade and the environment); DANIEL C. ESTY, GREENING THE GATT: TRADE, ENVIRONMENT AND THE FUTURE (1994) (analyzing policy failures that have contributed to the conflict created between freer trade and environmental protection); Steve Charnovitz, Environmentalism Confronts GATT Rules: Recent Developments and New Opportunities, 27 J. WORLD TRADE 37, 37 (1993) ("The purpose of this article is to discuss recent developments in the clash between environmental policies and GATT rules."); Daniel A. Farber \& Robert E. Hudec, GATT Legal Restraints on Domestic Environmental Regulations, in FAIR TRADE AND HARMONIZATION, supra note 18, at 59 (examining the conflict between trade and the environment); OREN PEREZ, ECOlOGICAL SENSITIVITY AND Global LeGal PluRALISM: RETHINKING THE TRADE AND ENVIRONMENT CONFLICT (2003) (arguing that the tension between trade liberalization and environmental protection, in its focus on the WTO, fails take aspects of institutional and discursive complexity into account). 
options reasonably available to it to pursue its dolphin protection objectives through measures consistent with the GATT, in particular through the negotiation of international cooperative arrangements..." 85 This would seem to imply that if such an agreement had been reached, or at least sought, 86 the exception could be invoked. Nevertheless, the legal status of multilateral environmental agreements ("MEAs") within the WTO regime is still unclear, and a new agreement clarifying this relationship and granting recognition to standards set by such an agreement would do much to solve the current tension.

In Doha, it was agreed to start negotiations on the relationship between MEAs and existing WTO rules. ${ }^{87}$ These negotiations, however, are to be limited in scope to the applicability of such existing rules as among parties to the MEA in question, and may not prejudice the WTO rights of any member that is not a party to the MEA in question. Thus, once such an agreement is reached-and it would appear to be a quite likely component of any new multilateral trade deal-it could facilitate the harmonization of minimum environmental standards around the world according to the standards set by the relevant MEAs ${ }^{88}$ - but only in relation to those Member States that are parties to these MEAs. Those that are not parties may not be forced to comply with such standards by trade sanctions that are in conflict with their WTO rights. But for those Member States that are parties to MEAs in question, the fact that their standards will be sanctioned by the WTO multilateral trading system will most likely strengthen them and contribute to their observance. ${ }^{89}$

85 United States Restrictions on Imports of Tuna, supra note 4, para. 5.28.

86 From later jurisprudence of the WTO it is evident that an actual agreement is not necessarily required, but rather, a sincere effort to negotiate one before resorting to unilateral trade restrictions. See WTO Appellate Body Report on United States - Import Prohibition of Certain Shrimp and Shrimp Products, paras. 166-72, WT/DS58/ AB/R (Oct. 12, 1998) (criticizing unilateral U.S. actions because of the lack of efforts to negotiate first).

87 Doha Declaration, supra note 68 , para. 31.

88 The extent of such harmonization would be similar to the extent agreed upon by the signatories of such multilateral environmental agreements ("MEAs"), which usually relate only to environmental problems with global or transnational aspects. Problems with purely domestic dimensions, which usually are not covered by MEAs, would be a matter for national regulation. This would also allow national regulators to consider special domestic needs and circumstances.

89 For instance, one possible outcome of such an agreement is that trade restrictions imposed pursuant to an MEA (for example, a ban on imports of products the production of which may harm the ozone layer pursuant to the 


\subsection{Examples of Other Potential Initiatives for the Future Approximation of Labour Standards}

The link between labour standards and international trade, and the claim that divergent national labour standards would create unfair competition, are as old as the GATT system itself. 90 It was expressed in the Havana Charter of the International Trade Organization ("ITO") of 1948, ${ }^{91}$ which was intended to provide the institutional framework for GATT, but which failed to gain the required ratification of the U.S. Congress, and therefore never saw the light of day. ${ }^{92}$ The Charter includes the declaration of its members that "unfair labour conditions, particularly in production for export, create difficulties in international trade, and accordingly, each Member [sic] shall take whatever action may be appropriate and feasible to eliminate such conditions within its territory." 93 In the GATT itself, the link received a much more modest, but at least operative, expression in Article XX(e), which provides an exception for otherwise prohibited trade measures, if such measures relate to the products of prison labour. Therefore, in view of the unfairness inherent in a situation where such products compete against domestic products produced by regularly paid free workers, WTO members are allowed, under certain conditions, to adopt trade restrictions against imports of such products. ${ }^{94}$ However, in relation

Montreal Protocol) will qualify for an exemption under Article XX of GATT. With the worry of a GATT violation out of the way, it will become easier to achieve more effective enforcement of MEAs. It is much less likely to expect an outcome whereby a breach of an MEA will qualify as a breach of one of the WTO agreements, which would enable the utilization of the strong enforcement mechanism of the WTO.

90 For an account of the history and politics of this link, see generally Virginia A. Leary, Workers' Rights and International Trade: The Social Clause (GATT, ILO, NAFTA, U.S. Laws), in FAIR TRADE AND HARMONIZATION, supra note 18, at 177-230.

91 Final Act and Related Documents of the United Nations Conference on Trade and Employment, Havana, Cuba, Mar. 24, 1948, U.N. Doc. ICITO/1/4 (1948), reprinted in CLAIR WILCOX, A CHARTER FOR WORLD TRADE 227 (1949) [hereinafter Havana Charter] .

92 For an account of the reasons that lead to the death of the Havana Charter, see for example WiLLIAM DiEBOLD, THE END OF THE I.T.O. (1952); JOHN H. JACKSON, WORLD TRADE AND THE LAW OF GATT: A Legal ANALYSIS OF THE GENERAL AGREEMENT OF TARIFFS AND TRADE 35-57 (1969);

93 Havana Charter, supra note 91 , art. 7.

94 See GATT, supra note 13, art. XX (excluding measures relating to prison labour from the scope of the agreement). The opening sentence ("chapeau") of Article XX sets out the conditions for invoking the exceptions listed in the article, which are that the otherwise prohibited measures are not applied "in a manner 
to any other circumstances of unequal labour conditions, there is no permission under the GATT, as it stands today, to take any protective measures against products from another Member State. Demands to broaden the existing exception to include "internationally recognized worker rights" have been raised by the United States (occasionally with the support of several European countries) ever since 1953, including at the end of the Uruguay Round. It also featured, as a central U.S. demand, in the discussions leading up to the Seattle Ministerial. ${ }^{95}$ The demand has, however, been met with staunch opposition from the developing countries, who see it as an attempt to restrict their exports to the developed world.

Following the precedent set by the TRIPS Agreement, this issue has now gained further steam. There can hardly be any doubt that the conditions under which workers are employed in the manufacture of goods (which then are exported or sold as import substitutes in the domestic market) are just as "trade-related" as the standards of protection of intellectual property rights, if not more so. Countries that do not guarantee and enforce basic labour standards have an undue cost advantage over those countries that do. Importcompeting and exporting firms in the latter countries may respond to this disadvantage by depressing wages or pressing their governments to lower the prevailing standards in order to enable them to compete, or, at a minimum, demands from labour unions to further raise the standards may be rejected based on the concern that this will further deteriorate the local industry's competitive position. The proponents of linking labour standards to trade within the

which would constitute a means of arbitrary or unjustifiable discrimination between countries where the same conditions prevail, or a disguised restriction on international trade." Id.

95 See, e.g., Attempt to get Labour on WTO Agenda Rejected, FIN. TIMES, Nov. 9, 1999. As part of the Seattle Ministerial preparations, the United States put forward a proposal to establish a WTO Working Group on labour issues. The proposal calls for a group to examine trade issues related to labour, specifically trade and employment, trade and social protections, trade and core labour standards, positive trade policies incentives and core labour standards, trade and forced or exploitative child labour, and trade and derogation from national labour standards. See Implementation Issues: The Rocky Road to Seattle, 3 BRIDGES: BETWEEN Trade AND Sustainable DevelopmeNT, No. 46, Nov. 24, 1999 (discussing Seattle Ministerial positions), available at http://www.ictsd.org/English/Bridges3-8.pdf. The U.S. position was a result of a Congressional mandate that the United States should seek such a working group. The request was also politically expedient to assuage a very vocal labour movement in the United States whose support is necessary to maintain U.S. momentum toward further trade liberalization. Id. 
WTO, therefore, argue that such linkage is necessary in order to prevent a "race to the bottom" in prevailing labour standards prompted by the globalization of the economy. In addition, there are, of course, the human rights aspects of such a linkage, particularly when we speak of basic core standards, the universal respect of which go far beyond economic considerations of fair competition. Indeed, many human rights activists are calling upon the WTO to use its effective enforcement mechanism, as well as the power of the entire international trading system in order to facilitate the enforcement of basic human rights, including workers' rights. 96

It is extremely unlikely that some open-ended exception clause, under which any differences in labour standards can serve as a justification for import restrictions or for import duties to "countervail the inequality," will ever be adopted in the WTO. The developing countries would never agree to that, and it is even doubtful whether some of the developed countries would. Even U.S. products could be countervailed under such a clause when imported into the EU considering that European workers generally enjoy a higher level of labour rights protection than in the United States. What could, however, be acceptable is some sort of an agreement on a linkage with "core labour standards" or minimum "internationally recognized worker's rights." This could be done in many different ways. For instance, WTO members could agree on some very fundamental standards, such as a prohibition against forced labour and child labour and the right to organize and bargain collectively. Such an agreement (which could be named Trade Related International Labour Rights, or "TRILs") would be made an integral part of the WTO's single undertaking, just like TRIPS is today. An existing precedent to such an approach in the field of labour standards is the North American Agreement on Labour Cooperation $^{97}$ that was signed in 1993 as a supplementary agreement to the NAFTA $^{98}$ to alleviate concerns about lax

96 See, e.g., Werner Meng, International Labour Standards and International Trade Law, in THE WELFARE STATE, GLOBALIZATION, AND INTERNATIONAL LAW 371 (Eyal Benvenisti \& Georg Nolte eds., 2004) (advocating cooperation between the WTO and the ILO to address the issue of labour standards affecting international trade). For a discussion of this argument, see Arie Reich, Core Labour Standards and the WTO: Beware of Unilateralism! - A Response to Werner Meng, in THE WELFARE STATE, GLOBALIZATION, AND INTERNATIONAL LAW 395; TREBILCOCK \& HOWSE, supra note 66, 188-89.

97 North American Agreement on Labour Cooperation, Sept. 14, 1993, 32 I.L.M. 1499.

98 See supra note 5. 
enforcement of labour standards in Mexico. Alternatively, instead of prescribing positive obligations in this field, the members could agree to extend the exception already existing in Article $X X(e)$ of the GATT to cases where these specifically defined core labour standards have not been met, causing unfair competitive conditions for domestic producers. This would allow Member States to restrict or countervail imports originating from such conditions of manufacturing, but it would probably not help very much when competing against them in third countries. ${ }^{99}$ The main problem with the second alternative is that it would allow Member States to take unilateral action, forcing affected Member States to challenge this trade impeding action through the WTO dispute settlement mechanism. Meanwhile, the trade-impeding measure would be in force, awaiting the conclusion of the dispute settlement proceedings and implementation procedures. ${ }^{100}$ The first alternative, in contrast, would only permit sanctions after multilateral authorization following an impartial examination of the claim that fundamental standards are not being respected in another Member State.

In any case, what we would have is an instrument within the WTO regime that facilitates harmonization-or at least approximation - of basic labour law standards in all Member States. These basic standards could be set by the WTO itself or more likely, by reference to existing international conventions as was done in TRIPS. In this way, the WTO would preclude the criticism that it meddles in affairs in which it has no expertise or in which it has not the appropriate institutional structure to regulate.101 The ILO, in contrast, has been initiating and promoting international labour conventions defining workers rights ever since its inception in 1919.

99 Here the high-standard country has no way to restrict the imports from the low-standard country into a third country, and that country may have no interest at all in restricting the importation of cheap goods into its market for the benefit of its consumers. What the high-standard country could perhaps do is to confer export-subsidies to its affected industries, helping them compete against the products from the low-standard country. While such subsidies are generally prohibited under the 1994 Subsidies Agreement, a general exception under Article XX of the GATT would permit them in these specific circumstances. See 1994 Subsidies Agreement, supra note 33, art. 20, para. 20.6.

100 For a discussion of the dangers to the multilateral trade system from such unilateral measures, see Reich, supra note 96, at 401-06.

101 The WTO is an organization in which only governments are members. Negotiations toward international agreements in the field of labour standards usually allow the participation of labour unions and employers, and permit ample representation of their interests in the process. 
It has a tripartite structure that allows not only the active participation of governments in the decision process, but of employers and workers as well. Therefore, some sort of collaboration between the two organizations in this respect would only seem natural. What would have to be negotiated is which of the ILO's many conventions relating to fundamental rights and principles ought to be included - and therefore enforceable - within the WTO regime. Labour unions, especially in developed countries, would prefer an extensive list of rights -including rights to just and favourable conditions of work, fair wages, safe and healthy working conditions and protection against unemployment. This is very unlikely to ever get the approval of developing countries. More realistic proposals speak of a more limited gamut, namely freedom of association, right to collective bargaining, prohibition on forced labour and severe forms of child labour, and discrimination in employment. To reach an agreement on this, no doubt some sort of bargain will have to be struck with the developing countries, granting them concessions in the fields of their interest, such as textiles and agriculture. What is very feasible, judging from experience in other GATT contexts, is that initially a very limited list of rights will be agreed on-for instance, forced labour and a relatively low minimum age for the employment of children - just in order to "get a foot in the door," while further extension of the list would await future negotiations. ${ }^{102}$

\subsubsection{Harmonization of Product Liability Law}

Products moving across borders have been the business of GATT ever since its inception in 1947. One of the factors that may influence the marketing of products is the problem of product liability, i.e., the extent to which the manufacturer, importers, or distributors can be held liable for any damage caused by a defective product. The laws and legal environment governing product liability differ considerably from state to state, and these differences may cause barriers to the free flow of trade and distort international competition. For instance, a jurisdiction with strict tort liability for defective products, and where punitive damages are often imposed on manufacturers of such products in serious bodily injury cases,

102 For alternative solutions to this problem, see Reich, supra note 96, at 406-09 (suggesting possible approaches such as establishing a non-political international mechanism to promote core labour standards and creating a system of positive incentives). 
places a heavy cost on manufacturers operating within it. This cost may be manifested in actual payments of damages, in litigation costs, or in high liability insurance premiums, coupled with indirect costs in connection with damaged reputation. ${ }^{103}$ In contrast, manufacturers operating in jurisdictions with a low standard of liability, such as a regular negligence standard with no compensation for pain and suffering, no punitive damages, and where caps are placed on other compensatory damages, save themselves these costs and may consequently be able to sell their products at lower prices. They may also enjoy another advantage over their competitors in other jurisdictions because they can test their new products in their home markets for potential liability without encountering crippling litigation and liability costs before moving on to foreign markets with higher liability standards.104 Thus, harmonization of product liability standards in WTO member countries could be another possible project for the WTO in line with its new mandate of "leveling playing fields" and harmonizing conditions of competition.

Indeed, the EC, in the early 1980s, recognized the trade impact of diverging liability standards and initiated a harmonization directive. The Directive, 105 adopted in 1985, purports to harmonize the laws on

103 See Katherine A. Davies, An International Drug Administration: Curing Uncertainty in International Pharmaceutical Product Liability, 18 NW. J. INT'L L. \& Bus. $685,710-11$ (1998) (noting the increase in costs pharmaceutical companies are. experiencing due to product liability, including litigation costs, excessive jury awards, high insurance premiums, and heightened marketing costs of counteracting negative publicity). Insurance premiums have skyrocketed in recent years due to the difficulty to calculate the risks associated with pharmaceutical production in today's U.S. litigation and liability climate); see also Christoph Ann, Innovators in the Crossfire: A Policy Sketch for Unknowable Risks in European and United States Product Liability Law, 10 TUL. EUR. \& CIV. L.F. 173, 183 (1995) (giving reasons for not including innovation risks in product liability and suggesting the externalization of damages be put on non-innovative producers).

104 See Alfred E. Mottur, The European Product Liability Directive: A Comparison with U.S. Law, an Analysis of its Impact on Trade, and a Recommendation for Reform so as to Accomplish Harmonization and Consumer Protection, 25 LAW \& POL'Y INT'L BUS. 983, 1008 (1994) (arguing that European companies will not shy away from the innovation and risk-taking that is discouraged in the U.S. market by the fear of liability and its concurrent high costs. "If a company's product can hold up under the [EC legal regime], then it can export them to the United States, more confident that they will not be the subject of suit there.").

105 Council Directive 85/374, 1985 O.J. (L 210) 29, reprinted in EUROPEAN COMMUNITY LAW SELECTED DOCUMENTS 642-48 (George A. Bermann et al. eds., 1993) (adopting a directive on the Approximation of the Laws, Regulations, and Administrative provisions of the Member States Concerning Liability for Defective Productions). 
product liability within the EC Member States to create a level competitive playing field, promote the free movement of goods and raise the standard of consumer protection within the Community. The preamble states:

Whereas approximation of the laws of the Member States concerning the liability of the producer for damage caused by the defectiveness of his products is necessary because the existing divergences may distort competition and affect the movement of goods within the common market and entail a differing degree of protection of the consumer against damage caused by a defective product to his health or property ....106

The Directive establishes a strict liability standard, i.e., liability without fault, subject to only a few defenses and requires EC Member States to implement this standard in their respective legal systems. Considering the inherent difficulty in proving negligence of manufacturers, given the inability of plaintiffs to access technical information and expertise, such legal change is very helpful to potential victims of defective products. In order to succeed in a lawsuit, all they have to prove is the defect in the product, the damage suffered, and the causal link between the two.107 Besides ensuring compensation to victims, strict liability also increases manufacturers' incentive to provide satisfactory product safety.

Thus, in addition to the "leveling of playing fields" rationale, a WTO harmonization initiative in the field of product liability would also fit in with the declared objective of the WTO and the GATT of "raising standards of living." 108 By increasing liability and raising safety standards of traded products in all its Member States, the WTO would make an important contribution to the welfare of consumers all over the world in a field that is still connected to its traditional main area of competence-trade in goods. By doing so, it would also respond to the common criticism that it only caters to the

106 Id. pmbl., at 642.

107 Id. art. 4 ("The injured person shall be required to prove the damage, the defect and the causal relationship between defect and damage.").

108 See the First Preamble of the WTO agreement, supra note 13, at 6; GATT, supra note 13 , at 486 . 
interests of business and multinationals and not to "plain people,"109 and perhaps improve its rather battered public image.

\subsubsection{Other Potential Areas: Tax Policies, Company Law, Consumer Protection.}

In line with the types of rationales raised in the discussion above, several other areas could, in the future, become potential targets for harmonization within the WTO. One such area is tax policy. Here too, the rationale for harmonization would be to equalize conditions of competition and to prevent harmful tax competition between states struggling to attract capital investments to their respective jurisdictions. Because in our era of globalization, capital is more mobile than labour, both developed and developing countries are forced to lower their capital tax rates, depriving them of revenue and forcing them to rely on labour tax and other forms of taxation less progressive than the income tax.110 The only way to stop the "race to the bottom," which has created a serious threat to the welfare state, is by international cooperation aimed at harmonization.111 One likely forum for such harmonization is the WTO. While tax policy hitherto has not been within the express mandate of the WTO, some national tax measures may come into conflict with the WTO Agreement on Subsidies and Countervailing

109 The criticism is even quoted on the WTO website as a "common misunderstanding" about the WTO. The World Trade Organization, 10 Common Misunderstandings About the WTO [hereinafter Common Misunderstandings], available at http://www.wto.org/english/thewto_e/whatis_e/10mis_e/10m00_e. htm (last visited Feb. 16, 2004).

110 See Reuven S. Avi-Yonah, Globalization, Tax Competition, and the Fiscal Crisis of the Welfare State, 113 HARV. L. REV. 1573 (2000) ("Tax competition has resulted in a significant potential for evasion and avoidance of taxation on the income from cross-border portfolio and direct investments, which may lead to significant tax base erosion and revenue losses."); Mathew Bishop, Special Survey: Globalization and Tax, 354 ECONOMIST, Jan. 29, 2000, iss. 8155 (discussing costs and benefits of internal tax competition).

111 See Avi-Yonah, supra note 110. However, Avi-Yonah proposes that such harmonization is done through the Organisation of Economic Co-operation and Development ("OECD"). Id. at 1662. Since this organization includes only developed countries, it would mean that developing countries would not be bound by the agreements. It is questionable whether this would be enough to prevent harmful tax competition. Avi-Yonah argues that the OECD members are currently both the destination of most portfolio investments and the largest markets, and they are therefore best positioned to implement changes. However, if the ability to use these countries as tax havens is eliminated, new markets may evolve outside the OECD. Id. at 1665-66. 
Measures, ${ }^{112}$ and this in turn has led to some much debated dispute settlement procedures between the European Union ("EU") and the United States. ${ }^{113}$ A new harmonization measure within the WTO, however, would probably not deal with fiscal export subsidies, but rather strive to set minimum standards or levels of capital taxation. Here too, harmonization within the WTO would follow the precedent of the EU, which has adopted-albeit with much difficulty-several measures designed to tackle harmful tax competition. ${ }^{114}$

Other potential areas for multilateral harmonization within the WTO could be company law, ${ }^{115}$ consumer-protection law, ${ }^{116}$ and

112 See 1994 Subsidies Agreement, supra note 33, art. 1.1(a)(1)(ii) (providing that a subsidy shall be deemed to exist if "government revenue that is otherwise due is foregone or not collected" and indicating expressly that "fiscal incentives such as tax credits" fall within this category).

113 The most recent one is WTO Panel Report on United States-Tax Treatment of "Foreign Sales Corporations", WT/DS108/R (Oct. 8, 1999). This was appealed in WTO Appellate Body Report on United States-Tax Treatment for "Foreign Sales Corporations", WT/DS108/ AB/R (Feb. 24, 2000).

114 See Conclusions of the ECOFIN Council Meeting Concerning Taxation Policy, 1998 O.J. (C 2) 1; Commission Proposal for a Council Directive to Ensure Effective Taxation of Savings Income in the Form of Interest Payments within the Community, 2001 O.J. (C 270E) 259. The European Union ("EU") package included three measures: a nonbinding "code of conduct" for business taxation, a draft directive on taxation of savings, and a draft directive on taxation of crossborder interest and royalty payments.

115 The rationale for harmonization of company law would also be to prevent a "race to the bottom" in regulation of company law in order to attract foreign investors and prevent local investors from registering their companies in foreign, more "founder-friendly" jurisdictions. Such jurisdictions also create advantages for its corporations in relation to other jurisdictions. For instance, a corporation established in a jurisdiction with high standards of directors' liability has to pay significant sums for directors' liability insurance premiums, while a company established in a jurisdiction with no such liability saves itself such costs. A race to the bottom in this connection has been claimed to exist between the state jurisdictions of the United States and has therefore produced calls for federal regulation. See William L. Cary, Federalism and Corporate Law: Reflections upon Delaware, 83 YALE L.J. 663, 666 (1974) ("It is clear that the major protections to investors, creditors, employees, customers, and the general public... must continue to come, from Federal legislation. ..."); Daniel R. Fischel, The "Race to the Bottom" Revisited: Reflections on Recent Developments in Delaware's Corporation Law, 76 Nw. U. L. REV. 913 (1982) (stating Delaware's enabling corporation statute does not fail to provide adequate protection to shareholders); Stanley A. Kaplan, Fiduciary Responsibility in the Management of the Corporation, 31 BUS. LAW. 883 (1976) (discussing whether state or federal regulation is more appropriate).

116 The rationales for harmonization in the field of consumer law are similar to those described above in relation to product liability law. Firms operating in jurisdictions with strict consumer protection laws incur higher costs than those 
other fields of intellectual property law. ${ }^{117}$

\section{IMPLICATIONS OF THE INSTITUTIONAL SETTING: THE PROS AND CONS OF HARMONIZATION THROUGH THE WTO}

As shown in the previous Section, the potential for harmonization of law and economic policies through the WTO is almost boundless. Of course, that is not to say that all of the potential will materialize or that it is going to be easy to reach consensus even on those initiatives that have already been raised within the organization. In fact, the political obstacles are huge and it is still unclear whether the WTO will be able to even launch negotiations on some of the "new" Doha issues given that "explicit consensus" is required.118 The recent collapse of the Cancún Ministerial, without consensus on any of the items on its agenda and, in particular, amidst bitter divisions over these very issues, raises the serious question of whether the WTO has not overextended its mandate. Indeed, the larger the membership of the organization gets, the harder it is going to be to reach an agreement on a deal, and the recent accession of the People's Republic of China may make things even more complicated. Nevertheless, at least some of the initiatives have a good chance to materialize in some form or another in the not too distant future, just like some of the initiatives which looked very unlikely only a decade ago have already materialized following the Uruguay Round - to the surprise of many observers. It, therefore, is important to be aware of this unofficial role that the WTO is playing as a

operating in jurisdictions with lax consumer protection laws. In addition, the mere divergence in these laws create barriers to the free flow of goods and impose costs on producers who must try to conform with the many different standards and requirements of the various jurisdictions to which their products are exported. Some of these problems, as far as they relate to technical standards, are already part of the WTO mandate and are regulated (albeit not very successfully) by the Agreement on Technical Barriers to Trade, but most other issues usually regulated by national consumer protection laws are still outside the scope of any WTO agreement.

117 Several contentious issues in intellectual property law were not resolved by the TRIPS Agreement and may be dealt with in future agreements. For instance, the agreement did not address the issue of parallel imports (importation of genuine products by an importer unauthorized by the manufacturer and owner of the trademark or patent of the products) and several issues in connection with geographical indications.

118 See Doha Declaration, supra note 68, paras. 23, 26 (relating to competition policy and government procurement respectively). The same applies to investment. Id para. 20. 
harmonizing institution and to evaluate its advantages and disadvantages when compared to the work of traditional institutions of harmonization. In light of the problems that will be identified, we will then try to suggest improvements to the "legislative" process of the WTO so as to make it more fit for the new role that it has assumed.

It should be stressed that we do not attempt to evaluate the normative case for or against harmonization of law per se. This is a contentious issue that has been discussed in the literature.119 Rather, we start from the conclusion reached above that harmonization has taken place within the WTO, and that there is a good chance that the organization will continue to play an important role in this field. That being the case, one should consider its institutional aptness to such a task.

\subsection{The WTO vs. Traditional Harmonizing Institutions: Equalizing}

Terms of Competition vs. Reducing Differences in National

Laws - Different Obstacles, Different Solutions

Harmonization of commercial and trade law is motivated by three major factors, all of which are strongly connected and fueled by globalization:

- the wish to eliminate those obstacles to international commercial activities that are caused by differences in national laws and regulations;

- the desire to equalize terms of competition and "level the playing field" in order to promote global efficiency or to prevent what are perceived as unfair trading conditions; and

- mutual cultural and ideological influences.

The last factor, which is outside the scope of the present Article,

119 See generally Rene David, The International Unification of Private Law, in II-5 INTERNATIONAL ENCYCLOPEDIA OF COMPARATIVE LAW; KONRAD ZWEIGERT \& HEIN KOTZ, INTRODUCTION TO COMPARATTVE LAW (2d revised ed. 1987); Martin Boodman, The Myth of Harmonization of Laws, 39 AM. J. COMP. L. 699 (1991) (analyzing harmonization as a vehicle for legal reform); David W. Leebron, Claims for Harmonization: A Theoretical Framework, 27 CAN. Bus. L.J. 63 (1996) (proposing an analytical framework for assessing the potential worth of harmonization); Paul B. Stephan, The Futility of Unification and Harmonization in International Commercial Law, 39 VA. J. INT'L L. 743 (1999) (criticizing harmonization and questioning its benefits to facilitate international commercial transactions). 
does not need any international organization to materialize. It is largely a spontaneous reaction to global changes, where ideological and technological developments create greater openness and awareness to what is happening in other jurisdictions, and this in turn has its impact on both the legislative and judicial process in many countries. In today's global society, legislators and judges have greater access to information about the legal systems of other countries and their relative success or failure. They are, therefore, more able to base the design of their legislative or judicial initiatives on foreign models and, in particular, on successful ones. As a result, these will tend to spread internationally, more so than the less successful ones.

But coming back to the first two factors - it is here that the WTO differs from most other law-harmonizing institutions. For the WTO, the most prominent rationale for harmonization is the first one-the wish to eliminate differences in order to make it easier to trade across borders and to make the legal environment of international business more stable and predictable. In this category we have important harmonization instruments such as the UNCITRAL Convention on Contracts for the International Sale of Goods, ${ }^{120}$ the Uniform Customs and Practices for Documentary Credits issued by the International Chamber of Commerce ("ICC"), 121 the UNIDROIT's Convention on International Interests in Mobile Equipment, ${ }^{122}$ and the various international conventions on transportation law, such as the Warsaw Convention ${ }^{123}$ and the

120 United Nations Convention on Contracts for the International Sale of Goods, Apr. 11, 1980, 1489 U.N.T.S. 58 (adopting uniform rules governing the international sale of goods), available at http://www.uncitral.org/english/texts/ sales/CISG.htm.

121 INT'L Chamber of COMMERCE, Pub. No. 500, ICC UNIFORM Customs AND PRACTICE FOR DOCUMENTARY CREDITS (1993) (promulgating international rules on the role of banks in international transactions).

122 The convention was adopted at a diplomatic conference held in Cape Town, South Africa under the auspices of UNIDROIT and the International Civil Aviation Organization in 2001, and has been signed so far by 26 states, including the United States. Its objective is to facilitate the financing of the acquisition and use of mobile equipment of high value (such as aircraft, trains, containers, oilrigs, etc.). See Convention on International Interests in Mobile Equipment, Nov. 16, 2001 (citing information about its working procedures), available at http://www.unidroit.org/english/conventions/mobile-equipment/mobileequipment.pdf.

123 Convention for the Unification of Certain Rules Relating to International Carriage by Air, Oct. 12, 1929, 261 U.N.T.S. 423, (adopting harmonized rules regulating air transport), available at http://www.jus.uio.no/Im/air.carriage.war 
Hague-Visby Rules ${ }^{124}$ to name just a few. When faced with such harmonization initiatives, few countries have an inherent interest in maintaining the existing situation of divergence. Its exporters and importers of goods, services, or capital are likely to suffer from the disharmony just as much as those of other countries. The main difficulty facing the harmonizing institution, therefore, is to convince the country that the proposed international instrument is a better legislative measure than the one existing in the national system, or at least not inferior to it, and that the gains of uniformity outweigh the benefit of sticking to the existing and well-known system. In the WTO, however, the main impetus for lawharmonizing initiatives, in particular in the "new" and future fields, is the desire to level the playing field. ${ }^{125}$

Here we often encounter an almost inherent difficulty: there is at least one country - and often more than one-that benefits from the existing situation, and whose producers hence enjoy an advantage over those in other countries. It has therefore no interest in harmonization. On the contrary, harmonization is against its national interest. In this simple fact lie both the advantage and disadvantage of the WTO as a law-harmonizing institution. The disadvantage is in the inherent difficulty that this situation poses for the harmonization initiative. So long as full consent to the initiative is required from all related parties, the only way to obtain the consent of the disinterested party is to offer it some other type of benefit in exchange for its agreement to bind itself to the harmonizing measure and to give up its current advantage. But herein also lies the advantage of the WTO over other institutions. It has the ability that other institutions lack to offer that other benefit to uninterested parties in order to make it worth their while. Alternatively, it can threaten to withdraw benefits that such

saw.convention.1929/doc.html.

124 International Convention for the Unification of Certain Rules of Law Relating to Bills of Lading, Aug. 25, 1924, 120 L.N.T.S. 155 [hereinafter Hague Rules], as amended by the Protocol to Amend the International Convention for the Unification of Certain Rules of Law Relating to Bills of Lading, Feb. 23, 1968, 1412 U.N.T.S. 127 ("Visby Amendments"), available at http://www.jus.uio.no/lm/sea .carriage.hague.visby.rules.1968/doc.html.

125 For instance, the TRIPS Agreement, the new initiatives in the field of government procurement and competition policy, and possible future initiatives in labour standards, product liability, consumer protection, company law, and tax law. Some of these initiatives have other rationales as well, but this does not affect the soundness of the arguments that follow. 
uninterested parties have been enjoying within the organization if they refuse to join a new "package deal" negotiated within its auspices. Due to the wide range of issues that are subject to the WTO regime, the framework can offer a wide array of bargaining opportunities - including "cross-section" bargains - that may allow consensus building between very different economies.

This advantage is what has enabled the WTO to succeed where other institutions have failed. Take the World Intellectual Property Organization ("WIPO"), for instance, which for many years was unable to obtain the accession of several developing countries to its conventions on intellectual property. The organization also suffered severely from a weak dispute settlement mechanism and a weak enforcement mechanism. ${ }^{126}$ It was the WTO that managed to obtain the commitments from those countries to abide by the WIPO conventions, and it succeeded in this task by making those commitments a part of the package deal ("the single undertaking") of the newly established organization. ${ }^{127}$ Countries could not become members of the WTO unless they agreed to commit themselves to the entire package, including the new TRIPS Agreement. ${ }^{128}$ No country could afford to remain outside the WTO lest it was willing to cut itself out of the global economy.

The United States and some other WTO members are now trying to duplicate that success in the field of government procurement. Here, too, we have a previous attempt by a traditional (and less powerful) harmonizing institution, namely the UNCITRAL, to convince countries (in particular developing countries) to pass

126 See Robert J. Pechman, Seeking Multilateral Protection for Intellectual Property: The United States "TRIPS" Over Special 301, 7 MINN. J. GLOBAL TRADE 179, 182-83 (1998) (discussing the weakness of the Paris Convention and the International Court of Justice as enforcement mechanisms).

127 Since the enactment of the WTO Agreement in 1995, the World Intellectual Property Organization has experienced a major increase in its membership, which stands today at 179 , and the membership to those of its conventions that are supported by the TRIPS Agreement. Almost all of the new signatories are developing countries, many of which have signed the conventions following their accession to the WTO. See, e.g., WIPO, Notifications: Berne Convention (listing nations acceding to the Berne Convention for the Protection of Literary and Artistic Works since 1995), at http://www.wipo.org/treaties/en/ShowResults .jsp?search_what=N\&treaty_id=15 (last visited Feb. 26, 2004); WIPO, Notifications: Paris Convention (listing nations acceding to the Paris Convention for the Protection of Industrial Property since 1995), at http:/ / www.wipo.org/treaties/ en/ShowResults.jsp?search_what=N\&treaty_id=2 (last visited Feb. 26, 2004).

128 For a more detailed discussion of the TRIPS Agreement, see the discussion supra Section 3.5. 
legislation regulating their procurement activities. The UNCITRAL already recognized in the mid $1980 \mathrm{~s}^{129}$ that many developing countries suffered from a lack of legislation in this important field of government activity and spending, and that this impeded their economic development. After extensive work, in 1993 it adopted a Model Law on Procurement of Goods and Construction ("Model Law") and in 1994 a broader version also covering procurement of services. ${ }^{130}$ Had the Model Law been adopted by a large number of countries, it would have contributed significantly not only to greater transparency, fairness, and objectivity in the procurement process, but also to greater uniformity in the procurement laws around the world. The Model Law, however, has failed to gain wide acceptance, and to date only eighteen developing countries have enacted legislation based on or largely inspired by it. ${ }^{131}$ The World Bank has also worked on promoting regulation of government procurement for some time now and, on occasion, made it a condition for granting loans, but only with modest success. ${ }^{132}$

In the field of procurement, it is not necessarily a genuine interest of the disinterested country that serves as the obstacle, but rather a genuine interest of the ruling class, politicians, and civil servants who sometimes take advantage of the existing unregulated situation by extracting bribes and other benefits from firms wishing to contract with their government. It is with this situation in mind that the United States, the EU, and others are pressing for the inclusion of an Agreement on Transparency in Government

129 At its nineteenth session in 1986, the UNCITRAL decided to undertake work in the area of procurement as a matter of priority and entrusted that work to the Working Group on the New International Economic Order. See Report of the U.N. Commission on International Trade Law, U.N. GAOR, 41st Sess., Supp. No. 17, para. 243, U.N. Doc. A/41/17 (1986) (prioritizing procurement in the Commission's agenda).

130 UINCITRAL Model Law on Procurement of Goods, Construction and Services, U.N. GAOR, 49th Sess., Supp. No. 17, Annex 1, U.N. Doc. A/49/17 (1994), revised by U.N. Doc. A/49/17/Corr.1 (1994) [hereinafter UNCITRAL Model Law on Procurement of Goods].

131 See UNCITRAL, Status of Conventions and Model Laws, sec. 12 (detailing which nations used the Model law, at http://www.uncitral.org/english/status/ index.htm (last visited Feb. 26, 2004)).

132 See THE WORLD BANK, GUIDELINES: PROCUREMENT UNDER IBRD LOANS AND IDA CREDITS, sec. 2 (Jan. 21, 1995) (regulating procurement for projects founded by the World Bank), available at http:/ / siteresources.worldbank.org/INTRO PROCUREMENT/RESOURCES/PROCUREMENT-Guidelines-November2003.pdf (last visited Feb. 26, 2004). 
Procurement within the single undertaking of the WTO.133 They are hoping that the WTO will succeed where other organizations have hitherto failed. Of course for that to happen, the rich countries will have to offer reciprocal benefits of some type or another within the WTO system to the developing countries, which otherwise will be reluctant to change the situation. Harnessing the WTO to the task of regulating the procurement sector will not only improve the chances of having a large number of countries submit to a harmonized procurement regime, but will also significantly improve the chances that it will be enforced given the WTO's relatively effective dispute settlement and enforcement mechanism.

\subsection{Problems with Harmonization through the WTO}

In view of the special appeal of using the WTO for such and other harmonization initiatives, it becomes increasingly important to examine and evaluate the potential problems in connection with harmonization of law through the WTO, as compared to the bodies that hitherto have been performing this role. On the one hand, we enjoy the advantages of a highly developed institutional framework offering both a strong enforcement mechanism almost unprecedented in the sphere of international law, as well as a wide range of topics and interests that can be interconnected in a mutually advantageous bargain. On the other hand, a priori, there are bound to be problems when an institution that was established and designed in order to liberalize international trade, and not to deal with harmonization of law or of socioeconomic policies, is drawn into the latter task. These problems may emanate both from the structural characteristics of the institution, as well as from its political and ideological orientation. In the following Section, we will try to outline some of these potential problems. The question that emerges in view of them is how well founded and serious are the various concerns that we raise, whether the advantages outweigh the disadvantages, and what could be done to alleviate some of the problems.

\subsubsection{The Trade Bias}

By virtue of its mandate and orientation, the World Trade Organization is likely to be committed first and foremost to the promotion of international trade. Member States usually send their

133 See supra Section 3.3 (discussing government procurement). 
trade attachés to represent them in the organization, and the ministries in charge are usually trade or finance ministries. The WTO's major harmonization initiatives, as we have seen, have until now always been somewhat "trade related," even where they have significant impact on many non-trade aspects of regulation. It follows that in the design of harmonization initiatives within the WTO, there is bound to be a certain trade bias, i.e., a natural preference for objectives connected to trade promotion. This may come at the expense of other legitimate objectives and values. As long as the organization deals with "pure" trade issues, or issues whose trade component is dominant, this trade bias may be less of a problem. But as its mandate broadens, and it enters new areas where other objectives and interests play an important role, the trade bias may serve to distort the final outcome of the negotiations and tip the scales toward trade objectives at the expense of other goals or values. In addition, the WTO may lack the professional resources and experience required to design a regulatory regime outside its traditional field of expertise.

\subsubsection{The Mercantilist Ethos}

Another potential problem with using the WTO to promote harmonization initiatives is connected to the typical negotiation environment of this organization. The negotiations within the WTO, and within its predecessor the GATT, are characterized by a mercantilist ethos ${ }^{134}$ of give and take, where trade "concessions" in the form of mutual obligations to lower certain trade barriers are exchanged between nations until "a balanced outcome" has been reached. The negotiators sometime appear to perceive themselves as agents of their domestic industries, not of their domestic consumers, striving to maximize their export opportunities in return for a minimum amount of import opportunities. The achievements of each country's negotiation team are then measured according to the ratio of these two parameters - and not according to the extent to which the new agreement will contribute to the general welfare of their society. To negotiate a law-harmonization initiative aimed at producing the best possible global regulatory regime within a specific field in this type of polarized environment may not be conducive to the objective, and may produce a suboptimal regime.

134 Paul Krugman, What Should Trade Negotiators Negotiate About?, 35 J. ECON. LiteratuRE 113 (1997); PEREZ, supra note 84, ch. 3. 


\subsubsection{Too Politicized Framework}

Traditional law-harmonizing institutions, such as the UNIDROIT and UNCITRAL, are usually characterized as professional and relatively non-politicized bodies. In his account of the work on the UNCITRAL Convention on International Sale of Goods, Professor John Honnold, who served as the secretary of the organization when the convention was negotiated, traces the success of the convention to the fact that the representatives adopted "a flexible, international approach" whereby they would not try to bargain "in the spirit of tariff negotiations" for the maximum number of scraps of national law, 135 but would all join in the common effort to design the best possible international sales law. The fact that such an agreement could be reached is no doubt also related to the fact that none of the delegates were trade attachés or politicians, but rather academics and legal experts who were sent to the task because of their experience and expertise. ${ }^{136}$ The WTO, in contrast, is by its nature a much more politically charged forum and has become even more so in the last few years. ${ }^{137}$ Member States send their trade diplomats, not academics or private experts, to the WTO to negotiate the best possible deal for their countries. These trade negotiators often arrive with strict instructions from their governments and sometimes from their domestic industry, and are concerned about what they can and cannot agree to. These negotiators are not seeking to promote global welfare, rather to promote their respective national interests as perceived by their trade ministries. To let this forum negotiate a new harmonizing regime in an important legal or socioeconomic field-such as a global product liability convention-in the same way these

135 JOHN HONNOLD, UNIFORM LAW FOR INTERNATIONAL SALES UNDER THE 1980 UNITED NATIONS CONVENTION 51 (2d ed. 1991).

136 Id. (discussing UNCITRAL's representatives). Based on the UNCITRAL's basic charter found in G.A. Res. 2205, U.N. CITRAL, 21st Sess., at 99, U.N. Doc. A/6369 (1966), reprinted in [1968] 1 Y.B. Int'l Trade L. Comm'n 65, U.N. Doc. A/CN.9/SER.A/1970.

137 See Battle in Seattle, supra note 2 (explaining that following the fierce Seattle demonstrations, Sylvia Ostry, a former Canadian trade negotiator, recalled nostalgically how the previous trade negotiation round had been launched in 1986 in Punta del Este, a sleepy Uruguayan seaside resort, with no TV cameras, let alone demonstrators: "Faxes didn't arrive, and nor did our newspapers. It felt like we were on Mars.") 
delegates negotiate tariff concessions, by tit for tat bargaining, is not very likely to produce a high-quality legal regime.

On the other hand, one may argue that the analogy to the UNCITRAL Convention on International Sale of Goods is not necessarily legitimate. An international sales law that is to govern private international transactions between sellers and buyers is a much less contentious and controversial issue than many of the issues that are raised within the WTO. Since each nation has both sellers and buyers, the national interests of the representatives would hardly be served by bargaining for pro-seller or pro-buyer provisions or for trying to get a maximum number of scraps of national law into the convention. In relation to most of the WTO issues, however, where there are legitimate adverse interests of different countries and economies in different stages of development, one may argue that international regimes ought to be negotiated within a polarized forum where all these interests are represented to ensure a chance that the final outcome will represent some type of balanced compromise between these interests.

\subsubsection{The Democratic Deficit}

A problem frequently raised by WTO critics is the lack of democratic legitimacy to its legislative process. ${ }^{138}$ It is claimed that negotiations on the formulation of the rules are often shrouded under a heavy veil of secrecy, conducted by unelected diplomats negotiating, and eventually binding their governments and legislators to rules in relation to which "the people" or its legitimate representatives have had no real say. There has also been grave criticism against the WTO for not allowing NGOs, who represent various sections of society, to participate in the legislative process. ${ }^{139}$

138 This argument was first raised in the Trade \& Environment debate. See, e.g., Patti A. Goldman, Resolving the Trade and Environment Debate: In Search of a Neutral Forum and Neutral Principles, 49 WASH. LEE L. REV. 1279, 1285-86, 1296-98 (1992) (raising for the first time that the WTO lacks democratic legitimacy in its legislative process); G. Richard Shell, The Trade Stakeholders Model and Participation by Nonstate Parties in the World Trade Organization, 17 U. PA. J. INT'L ECON. L. 359 (1996) (discussing participatory non-state parties in the WTO); see also Benvenisti, supra note 96 , at 348-58 (presenting the role of the non-governmental organization ("NGO") in the legislative process).

139 See, e.g., Steve Charnowitz, Participation of Nongovernmental Organizations in the World Trade Organization, 17 U. PA. J. INT'L ECON. L. 331 (1996) (discussing the NGO's in the legislative process). 
Hence, as the mandate of the WTO is broadened and its proposed legal instruments affect more and more areas of concern for various interest groups-notably labour, environment, and consumer rights-requiring Member States to change laws adopted by democratically elected national legislators, this democratic deficiency becomes a serious problem.

\subsubsection{The Federal-State Problem}

The members of the WTO are states, represented by their central governments - not their subcentral governments, such as those of the states in the United States and the provinces in Canada. This may pose a problem for federal systems, where the jurisdiction in many areas of law is vested with the subcentral legislator. In a more specialized and less politicized framework, this problem could be more easily addressed. For instance, each subcentral government could send its representative to participate in the international legislative process. In the WTO, this may prove to be impossible due to the potential unwillingness of federal governments to cede authority and to create a problematic precedent in relation to the question of who runs the foreign trade policy. The GATT and the WTO have had some experience in this regard and it has not been entirely positive. ${ }^{140}$

\section{IMPROVEMENTS TO THE “LEGISLATIVE” PROCESS OF THE WTO}

In order to alleviate some of the problems described above, it would seem desirable that when dealing with the type of harmonization projects that have been discussed in Section 4 of this Article, the WTO needs to adopt a different approach and a different type of working procedure. In the paragraphs that follow, we shall make a few suggestions on possible changes, both in the basic philosophy of the organization and in its "legislative" process. The latter are merely examples of amendments, which, although rather conservative in their scope (taking into account the realpolitik of the WTO), may nevertheless be helpful in promoting a more conducive

140 Particularly relating to the Agreement on Government Procurement, which affects procurement by sub-central government entities as well. See, e.g., K.J. Cooper, To Compel or to Encourage: Seeking Compliance with International Trade Agreements at the State Level, 2 MiNN. J. GlobAL TRADE 143, 169 (1993) ("Recent disputes over state-level non-tariff trade barriers, as well as negotiations on government procurement, have reflected this dichotomy between what is legally possible, but practically difficult."). 
and balanced environment for WTO "legislation."

\subsection{Change in Outlook: The Need to Distinguish between Various Functions of the WTO}

Most of the problems described above are in essence the result of the new role assumed by the WTO, which is very different from the original role of the GATT as a facilitator of multilateral trade negotiations. The GATT method of conducting negotiations and formulating agreements was designed first and foremost with tariff bargaining in mind, as well as for negotiations on the lowering of other artificial trade barriers. These are typically tit for tat negotiations, polarized and rather confrontational, in the spirit of the mercantilist ethos. These negotiations are conducted by representatives of central governments, mostly trade officials, since it is they, and not subcentral governments, who usually have the exclusive power over custom tariffs and other border measures. Furthermore, the range of domestic interests affected is more limited than is the case under the new broadened mandate, thus raising less concern of democratic legitimacy.

A precondition to any solution of these problems is recognition among Member States of the change that has occurred and of the need to distinguish between the various functions of the WTO. There needs to be a realization within the WTO that new initiatives that involve new lawmaking or harmonization of domestic policies and laws are qualitatively different from the traditional tasks of the GATT/WTO and thus require different approaches and different negotiation techniques. One can hardly formulate and negotiate a new international code on competition law or product liability law in the same way that Member States have been negotiating tariff cuts under GATT or market access in service sectors under GATT. There is too high of a chance that such an approach will result in a patchwork of provisions reflecting some political compromise between opposing interests, rather than in a coherent and logical piece of legislation. There are enough examples of WTO texts of such incoherent outcomes that eventually serve no one well. Without a change in approach, there is a higher chance of breakdown in the negotiations toward potential welfare-enhancing agreements. ${ }^{141}$ By acknowledging the distinction between the

141 The various reasons for this will be discussed below and include the lack of professional expertise within the WTO staff in many non-trade areas, and more so among developing countries, and the "reactive devaluation" phenomenon that 
various projects of the WTO, traditional methods of negotiations may be maintained for the traditional projects, while new methods are developed for the new ones.

\subsection{The WTO in Comparison to Other Law-harmonizing Organizations}

The WTO is often categorized as a "member-driven" organization. ${ }^{142}$ All decisions within the organization are taken by its member countries, and almost always by consensus. "A majority vote is also possible but it has never been used in the WTO, and was extremely rare under the WTO's predecessor, GATT."143 Unlike many other international organizations, ${ }^{144}$ the WTO does not have an executive council composed of a subgroup of members, with the entire membership meeting only to decide matters that require action by all members. In the WTO, all the councils and committees are open to all members (148 as of today). For a new initiative to be included on the negotiations agenda for a new round, full agreement has to be reached between all member countries. In the course of the negotiations, as well, the initiative lies with member countries. The Secretariat plays a relatively minor role and only fulfills functions assigned to it by the decision of the members. Member countries are usually the ones who propose texts for the consideration of other members and these texts will often be met by counterproposals and different texts by other members. This process may sometimes lead the parties to "compromise" on some suboptimal mishmash of provisions devoid of coherence.

This method of international lawmaking is very different from the way institutions such as the UNCITRAL and UNIDROIT work when developing new conventions or other law-harmonizing measures. Unlike the WTO Secretariat, which has no real authority

is likely to hamper the negotiations in the absence of a third-party neutral facilitator.

142 See Common Misunderstandings, supra note 109 (describing the WTO as a member driven organization); see also Richard Blackhurst, The Capacity of the WTO to Fulfill Its Mandate, in THE WTO AS AN INTERNATIONAL ORGANIZATION 31, 32 (Anne Krueger ed., 1998).

143 The WTO website, The WTO in Brief: Part 2, at http://www.wto.org/ english/thewto_e/whatis_e/inbrief_e/inbr02_e.htm (last visited Feb. 27, 2004).

144 For example, the International Monetary Fund and the World Bank have executive boards, or the UNCITRAL whose Commission is made up of 36 Member States elected by the General Assembly of the United Nations. 
to initiate and formulate new proposals, in the UNIDROIT, for instance, the Secretariat plays a central role in the initiation and formulation of new conventions. The UNIDROIT Secretariat, assisted by an expert in the field when necessary, draws a preliminary comparative law report designed to ascertain the desirability and feasibility of a specific harmonization project. ${ }^{145}$ The approval of the organization's Work Program, including the undertaking of specific projects, is under the responsibility of the Governing Council, which also is a more professional than political body. It is composed of the President of the Institute, who is appointed by the Italian Government (the host country of the organization), and twenty-five elected members, typically eminent judges, practitioners, academics and civil servants. Once the Governing Council is satisfied that a case has been made for taking action, it will typically ask the Secretariat to convene a study group. The study group is traditionally chaired by a member of the Council. It is convened for the preparation of a preliminary draft convention or of another appropriate harmonization measure deemed more appropriate, such as a model law. The membership of such study groups, made up of experts sitting in their personal capacity, is a matter for the Secretariat, which seeks to ensure as balanced a representation as possible of the world's different legal and economic systems and geographic regions. Only after this preliminary instrument has been prepared does the process move into its intergovernmental negotiation phase with the establishment, by the Secretariat, of a committee of governmental experts for the finalization of a draft convention that is capable of submission for adoption to a diplomatic conference. 146 When the Council determines that the draft convention reflects a consensus among the States that have participated in the committee of governmental experts and that it accordingly stands a good chance of adoption at a diplomatic conference, the Council will transmit it to such a conference for adoption as an international convention.

A similar approach is reflected in the working procedures of

145 See UNIDROIT Official Web Site (citing information about the UNIDROIT's working procedures), at http://www.unidroit.org/english/ presentation/main.htm\#NR8 (last visited Feb. 17, 2004).

146 Provided the measure chosen is an international convention. In the case of an alternative measure, not suitable by virtue of its nature for transmission to a committee of governmental experts, the Council will be called upon to authorize its publication and dissemination by UNIDROIT in the circles for which it has been prepared. 
the UNCITRAL. ${ }^{147}$ The UNCITRAL, which is an organ of the United Nations ("U.N."), has a membership as of 2004 of sixty states (elected by the General Assembly for a term of six years from amongst Member States of the United Nations). The membership is structured so as to represent the various geographic regions and the principal economic and legal systems of the world. Usually, substantive preparatory work on topics on UNCITRAL's work program is assigned to a working group, which typically is made up not only of government officials (usually lawyers from the Ministries of Justice or Foreign Affairs, sometimes even high ranking judges), but also of well-regarded academics, experts or private sector lawyers. All Member States may send delegations to the Working Groups, and even nonmembers may send delegations to participate as observers. Sometimes the chairman of a working group will serve as such in his personal capacity, and not as a representative of his country, based on his expertise in the area. Assisted by professional members of the UNCITRAL Secretariat, the working group will prepare background papers and draft legal texts, which are then submitted to the annual session of UNCITRAL. In order to assist it with preparation of its work, the Secretariat frequently seeks the assistance of outside experts, conducting ad hoc consultations with individuals or convening meetings of groups of experts in a particular field as required. In addition, international intergovernmental and NGOs can participate as observers. For example, the ICC and UNIDROIT frequently have representatives attend the meetings. After a working group has prepared a draft text of a convention, model law or other instrument, it is submitted to UNCITRAL for consideration. UNCITRAL, governments, and international organizations may accompany it with an explanatory commentary on the draft text prepared by the Secretariat in order to assist its consideration. Generally, the draft text and the commentary, if prepared, are circulated to governments and interested international organizations for comment and the Secretariat may prepare an analysis of these comments. UNCITRAL is then able to undertake consideration of the draft text on the basis of those documents. If the text is a draft convention, the established practice is that UNCITRAL recommends to the U.N. General

147 The description of the working procedures of the UNCITRAL is based on a draft booklet on the UNCITRAL prepared by its Secretariat (on file with the author). 
Assembly that an international conference of plenipotentiaries be convened to finalize and adopt the convention and open it for signature. All in all, the formulation and negotiation process within the UNCITRAL of new legislative texts may be characterized as a professional and usually nonpolitical process, open to participation or observation of representatives from all interested states and sectors, and aimed at producing a text that is capable of obtaining the widest possible approval among potential signatories.

There are of course important differences between the nature of the WTO and its work and that of organizations such as the UNIDROIT and UNICTRAL. Perhaps the most important for our purpose is the fact that the latter two have no real force of coercion, and by transmitting a draft convention to a diplomatic conference they do not really exert any pressure, direct or indirect, on any country to adopt the proposed convention, to ratify it, or to ensure its enforcement. These actions are left entirely to the discretion of governments, and in the history of these two organizations there are many conventions that, although brought to a diplomatic conference, failed to attract sufficient ratification and consequently do not bind anyone. ${ }^{148}$ Given the need to ratify and often incorporate into legislation the new convention into the domestic law of each signatory, there will usually be some type of democratic decisionmaking process before its adoption. In contrast, while formally any new WTO instrument requires consent by all member countries, the reality of the "Single Undertaking" approach de facto leaves many countries no choice but to accept the package of agreements negotiated within a given

148 For instance, the United Nations Convention on International Bills of Exchange and International Promissory Notes (New York, 1988) needs ten ratifications in order to become binding, but has until now only been ratified by three countries. United Nations Commission on International Trade Law, para. IV (F), at http://www.jus.uio.no//m/uncitral/doc.html (last visited Feb. 29, 2004). The United Nations Convention on the Liability of Operators of Transport Terminals in International Trade (Vienna, 1991) requires only five ratifications in order to become binding, but has only been ratified by two countries until now. United Nations Convention on the Liability of Operators of Transport Terminals in International Trade (United Nations, 1994), at http:/ / www.jud.uio.no/Im/

un.transport.terminal.operators.liability.convention.1994/doc.html (last visited Feb. 29, 2004). Likewise, the UNIDROIT, Convention on Agency in the International Sale of Goods (1983) has only been ratified by five states and will only come into force when accepted by ten contracting states. See Covention on Agency in the International Sale of Goods (Geneva, Feb. 17, 1983), at http://www.jus.uio.no/lm/unidroit.agency.sog.convention.1983/portrait. 
round of the WTO. It is not surprising to find, therefore, much more sensitivity and resistance among many member countries, especially during the last few years following the experience of the Uruguay Round, toward the introduction of any new issue onto the negotiation agenda. This approach is also why one can hardly expect the same type of calm and nonpoliticized atmosphere in the WTO as in the UNIDROIT or in the UNCITRAL. Nevertheless, much could be learned from the experience of these organizations and the professional manner in which they develop harmonization initiatives. In particular, once the political decision has been made and it has been agreed by all WTO members to include a new issue involving law-harmonization on the negotiation agenda, the process would benefit from depoliticization and from having the formulations of the new text entrusted to a more professional and open procedure. To this end, much could be gained by strengthening the role of the Secretariat and other neutral professional bodies in the formulation and negotiation process.

\subsection{The Need for a Neutral Facilitator: Applying Insights from the Negotiation Literature}

The last decade has seen a surge in the research literature on negotiation and dispute resolution and some of it could shed light on possible solutions to many of the problems discussed above. One such solution is to use neutral facilitators in the negotiations that are actively involved in preparation of background studies and in the drafting of proposed texts, as well as in mediating between the parties in an effort to find common ground and to reach an agreement. There are many justifications in the literature to the advantages of such a function.

First, there may be several tactical and strategic barriers that preclude rational parties from reaching efficient outcomes in WTO style negotiations.

"Negotiators characteristically face a dilemma arising from the inherent tension between two different goals. The first goal consists of maximizing the joint value of the settlement-that is, the pool of benefits or size of the 'pie' to be divided. The second goal consists of maximizing their own share of the benefit pool-that is, the size and attractiveness of their particular 'slice' of pie." 149

149 Robert Mnookin \& Lee Ross, Introduction, in BARRIERS TO CONFLICT RESOLUTION 7 (Kenneth Arrow et al. eds., 1995) [hereinafter BARRIERS TO CONFLICT]. 
Often the strategies and tactics designed to maximize their own share tend to stand in the way of maximizing the pool for everyone, and may sometimes even shrink it. For instance, it may be perfectly rational for a negotiator to engage in tough and intransigent bargaining tactics in an effort to increase the size of his share. However, if more than one party employs such tactics, there is a high chance that an otherwise mutually beneficial deal may be put in jeopardy. Thus, if the formulation of proposed texts in a harmonization initiative is left exclusively to the parties, there is a high chance that each party will take a maximalist stance based on tactical considerations. Those subjected to such tactics often respond in kind, and the net result typically is, at best, additional cost of the negotiation process (loss of opportunity as a result of long delays) and, at worst, the failure to reach a mutually beneficial deal. A neutral intermediary may help to prevent such failure by fulfilling various functions: help each party to better prepare for the negotiations (focus on interests and explore reasonable expectations); help with neutral fact-finding; help with evaluation of offers and of analysis of interests; prepare more balanced proposals aimed at promoting common mutual interests and not motivated by strategic demands; facilitate interest-based negotiations between the parties; and help with generating efficient compromises, if required. ${ }^{150}$

Secondly, there may be psychological barriers in multiparty negotiations that may be overcome by the use of a neutral intermediary. As has been shown in many studies on negotiation and cognitive psychology, the fact that a certain proposal has been offered by someone "on the other side" often leads to a "reactive devaluation" of the proposal.151 Evidence obtained in both labouratory and field settings indicates that a given compromise proposal is rated less positively when proposed by an adversary than when proposed by an apparent neutral third party. A range of cognitive and motivational processes has been proposed to account for this phenomenon. These processes range from the perfectly rational tendency of negotiators to view an adversary's willingness to offer, rather than withhold a given concession as an indication of

150 Howard Raiffa, Analytical Barriers, in BARRIERS TO CONFLICT, supra note 149, at 143 .

151 For a discussion of the phenomenon and a review of the empirical evidence, see Lee Ross, Reactive Devaluation in Negotiation and Conflict Resolution, in BARRIERS TO CONFLICT, supra note 149, at 27. 
the advantages that it may bring to the adversary ("They wouldn't have offered those terms if those terms didn't advance their interests") and not to the recipient ("They wouldn't have offered those terms if those terms strengthened our position relative to theirs"), 152 to various cognitive biases, such as those documented by Kahneman and Tversky (for instance, the one termed "loss aversion," whereby the aversiveness of a given loss tends to be greater than the attractiveness of a gain of the same objective magnitude). ${ }^{153}$ These findings fit in well with the suspicious atmosphere that has evolved over the last few years within the WTO negotiation rounds, particularly in relation to the new harmonization projects, and they provide strong support to our argument that such projects will be better served by having a neutral and professional third party mediator or facilitator involved.

Thus, when dealing with harmonization projects a greater role needs to be given to professional, impartial bodies whose aim and mandate will be to serve the general, multilateral interest, and not the interest of one member state, or of a specific group of Member States. As is now the practice in the WTO, an official representative of one of the WTO members, a trade diplomat who is usually expected to serve the interest of his own country, could never fulfill such a function, even if temporarily appointed "Chair" or "Friend of the Chair" to facilitate certain negotiations - as is now the practice in the WTO. ${ }^{154}$ The facilitators have to be perceived by the negotiators as completely impartial and independent from any of the states involved in the negotiations. The authority and influence of such

152 Id. at 30.

153 Daniel Kahneman \& Amos Tversky, Choices, Values, and Frames, 39 AM. PSYCHOLOGIST 341, 342 (Apr. 1984). According to their findings, the very act of framing a proposal in a manner that invites the other side to give up some things it values in order to receive some other things it also values (as usually is the case in WTO negotiations) may leave the recipients of the proposal convinced that the loss in question will not be commensurate with the gain even when a prior elicitation of the recipients' values might have led one to anticipate that the proposed trade of concessions would be welcomed quite eagerly.

154 For instance, in the Cancún Ministerial, the draft ministerial text was first proposed by Ambassador Carlos Pérez del Castillo, a Uruguayan trade diplomat, who served as the Chair of the General Council. The whole meeting was presided by Mexican Minister of Foreign Affairs, Luis Ernesto Derbez, who appointed facilitators from among the representatives of various Member States: the representative of Singapore as the facilitator of agriculture negotiations; the representative of Hong Kong as the facilitator of industrial market access; and the representative of Argentina as the facilitator of the so-called "Singapore" issues including law-harmonizing projects. 
intermediary bodies would be conditioned upon them managing to establish and maintain their reputation of being professional and impartial in the eyes of the Member States, and to do so would thus be in their utmost interest. Their proposals and drafts would have to be capable of gaining the acceptance of all member countries, or at least the vast majority of them, in order to be successful, and this too would induce thoughtful consensus building and a higher quality of outcomes.

\subsection{Strengthening the Role of the Secretariat}

Improving the legislative process of the WTO would also require a greater role for the WTO Secretariat. ${ }^{155}$ Until now, member countries - in particular the larger countries-have made sure to keep the role of the WTO Secretariat as minimal as possible in the negotiation process, ${ }^{156}$ emphasizing the WTO as a "member driven" organization, as noted above. This system has naturally served the interests of those countries with stronger capacities and larger delegations to the organization in Geneva, who have the ability to promote new initiatives. Indeed, as has been shown by Blackhurst, 157 compared to other international economic organizations, the WTO Secretariat is very small in size and limited in its powers. While this model may have been appropriate for conventional negotiations on trade concessions, it is not conducive to optimal results in "new issues" negotiations aimed at achieving harmonization of domestic laws and policies. In such negotiations, the Secretariat ought to be empowered to undertake background studies, make proposals, and draw up draft texts for the consideration of member countries. For this purpose, the Secretariat ought to be authorized to employ the services of outside experts, such as academics, to assist it in its tasks.

155 See Constitution of the United Nations Educational, Scientific and Cultural Organization, art. VI para. 5 (stressing this character of the Director-General and the Secretariat: "The responsibilities of the Director-General and of the staff shall be exclusively international in character. In the discharge of their duties they shall not seek or recieve instructions from any government or from any authority external to the Organization."), available at http://www.unesco.org/comnat/azer baidjan/eng/about/constitution.pdf (last visited Mar. 4, 2004).

156 See Blackhurst, supra note 142, at 41.

157 Id. 


\subsection{A Permanent Council of Experts}

One could also suggest the establishment of a Permanent Council of Experts ("Council") composed of 10-12 independent and distinguished experts in law, economics and international trade. ${ }^{158}$ This Council would be authorized to consult the WTO and its Member States in relation to new harmonization initiatives -i.e., in all of the "new" issues proposed for new negotiation rounds, to propose such new initiatives, to commission and comment on background studies on such initiatives, and to prepare legal texts for the consideration of Member States. The Council should be authorized to hold public hearings on any new initiatives, where it would invite all parties with an interest in the issue at hand, including NGOs and subcentral governments, to make presentations and submit briefs and opinions. By establishing such a function, the WTO would make it clear that harmonization initiatives are materially different from other types of multilateral trade negotiations, and should therefore be approached in a more professional and less politicized manner, while simultaneously ensuring that all interested parties and all relevant perspectives on the issue are heard and considered. The Council could also propose tailor-made mechanisms whereby negotiations and drafting in specific areas should be made.

At the same time, however, the Member States would not be bound by the Council's proposals, and would maintain their sovereign right to oppose the proposals, to modify them, or to make alternative proposals. At the end of the day, it would have to be the Member States that came to an agreement whether or not to adopt a proposal, and if so to what extent. However, the fact that the process was initiated and accompanied by an independent professional body would lend it more authority and credibility. It would thus contribute significantly to alleviate some of the problems discussed above and to ensure a better product at the end

158 A certain precedent to such an institution, however much more restricted in its mandate, can be found in the WTO Agreement on Subsidies. See 1994 Subsidies Agreement, supra note 33. Article 24.3 of this agreement provides for the establishment of a Permanent Group of Experts ("Group”), composed of five independent persons, highly qualified in the fields of subsidies, and trade relations. The Group may be requested to assist a dispute settlement panel with regards to the question whether a measure that has been referred to the panel is a Prohibited Subsidy pursuant to the Agreement. Id. art. 24.3. Article 4.5 of the Agreement provides that the Group's conclusion on the issue must be accepted by the panel without modifications. Id. art. 4.5. 
of the process. It may also ensure that the interests of the developing and least developed countries would be considered more seriously, in view of the fact that under the existing system their lack of expertise in the complex issues on the WTO agenda considerably undermines their ability to look after their own interests.

\subsection{Cooperation with other International Organizations}

Finally, it would seem advisable that when dealing with issues that are within the mandate of other international organizations, or adjoined to their respective mandates, the WTO should cooperate with those institutions in order to take advantage of their experience and expertise, as well as of their institutional structure which may be more suitable to facilitate work in this specific field than that of the WTO. These institutions may have already created internationally agreed texts on the subject at hand, which could be adopted or referred to by the WTO agreement. Such texts (conventions, model laws, declarations, and so forth) would have a greater chance of being balanced, unbiased and of a higher-quality than texts negotiated within the traditional WTO atmosphere.

Thus, for instance, when dealing with the issue of trade and labour, the WTO ought to strengthen its cooperation with the ILO and make reference - to the extent that this will be agreed by WTO Member States - to internationally recognized ILO conventions on core labour standards. By such cooperation, the WTO would also take advantage of the ILO's tripartite structure, which allows not only the active participation of governments in the decision-making process, but of employers and workers as well. Likewise, in the proposed initiative on regulating government procurement procedures, ${ }^{159}$ the WTO ought to take advantage of the Model Law developed by UNCITRAL ${ }^{160}$ and of the experience with its implementation in developing countries, and use this Model Law as the basis for its proposed text in this field. Finally, in a possible initiative to negotiate a global consumer protection code, the WTO could use the U.N. General Assembly Resolution on Consumer

159 See discussion supra Section 4.1.1.

160 See UNCITRAL Model Law on Procurement of Goods, supra note 130 (developing laws on good procurement). 
Protection. ${ }^{161}$

\section{CONCLUSION AND DISCLAIMER}

The objective of this Article has been to draw attention to a somewhat neglected aspect of the World Trade Organization-its law-harmonizing function. As has been shown, this is a function that has evolved gradually, in particular during the last two negotiation rounds, and in stark contrast to a previous official policy of non-intervention with Member countries' domestic policies. The main causes of this transformation are the wish to eliminate obstacles to international commerce, caused by differences in national laws and regulations, and the desire to equalize terms of competition and "level the playing field." Based on these rationales, the Article has suggested several other areas where potential exists for law-harmonization by the WTO, some of which are already being discussed as possible items on the ongoing Doha Development Agenda, and others which have not yet been proposed but which we may perhaps find on future agendas. The rationales and potential for these various harmonization initiatives were discussed, as well as the realistic expectations in this regard in view of precedents from other international frameworks. The Article then discussed the relative advantages and disadvantages of the WTO, in relation to traditional law-harmonizing institutions, such as the UNIDROIT and UNCITRAL, concluding that its advantage lies in its ability to offer a wide array of bargaining opportunities - including "cross-section" bargains - that may allow consensus building between very different economies, as well as in its strong enforcement mechanism.

There are, however, many problems with harmonization within the WTO framework, some of which stem from the structural characteristics of the organization, and others from its political and ideological orientation. The Article outlined some of these problems, and then proposed several improvements to the "legislative" process of the WTO aimed at making it more apt for its new role as a law-harmonizing institution. A precondition for any change in this regard is an understanding among WTO members of the need to distinguish between the various functions of the WTO

161 G.A. Res. 248, U.N. GAOR, 39th Sess., U.N. Doc. A/RES/39/248 (1995), reprinted in 24 I.L.M. 914 (1985). See Patrizio Merciai, Consumer Protection and the United Nations, 20 J. WORLD TRADE 206 (1986). 
and a realization that harmonization of domestic policies and laws are qualitatively different from the traditional tasks of the GATT/WTO and thus require different approaches and different negotiation techniques. These approaches and techniques can be learned from the practice of traditional law-harmonizing institutions. Thus, one of the suggested changes is to employ the good services of a neutral facilitator or intermediary. This may include the establishment of a new professional and impartial body within the WTO whose aim and mandate will be to serve the general, multilateral interest of the WTO and its members, the strengthening of the role of the WTO Secretariat, and the establishment of a permanent council of experts. It is also recommended that the WTO strengthen its cooperation with other international organizations that have been involved in relevant harmonization initiatives, in order to take advantage of their experience and expertise, as well as their institutional structure which may be more suitable to facilitate work in this specific field than that of the WTO.

However, even if these improvements are made-and even more so if not-it is not certain that the WTO in its present situation, or in the near future, is capable of undertaking any new harmonization projects. In the strength of the WTO-its wide spectrum of subject matters, its large membership and its strong enforcement mechanism-lies also its weakness. During the last few years, and in particular after the recent failed Cancún Ministerial, the organization appears to be bogged down by the deep disagreements on the traditional trade issues, in particular agriculture. The developed countries' unreasonable refusal to do away with their huge agricultural subsidies and high textile tariffs has caused resentment among the developing countries and a refusal on their part to consider any of the "new issues," which in essence are harmonization projects (in particular competition and government procurement). With a consensus-based system and a growing membership (currently 148 countries), it will become harder to reach agreements on these contentious issues, and the introduction of yet additional issues may be unwise. Perhaps the faltering WTO is suffering from an overload of projects. If the multilateral system collapses, many of the rich countries are likely to turn to alternative venues, namely bilateral and regional trade agreements, and many of the harmonization projects may be pursued within such frameworks.

On the other hand, the world has much to lose from a collapse of 
the multilateral system, especially the poor countries that are not connected to any of the regional groupings of the major trading blocks. There is still a common interest in the revival of the Doha negotiation round, despite the many obstacles, and the fact is that many of the previous successful negotiation rounds also went through several crises until the eventual agreement was reached. For the developed countries to agree to abandon their heavy protection of domestic farms, they need to be offered something significant in return. At least some of the "new issues" are likely to be part of a package deal that may break the current impasse.

As for some of the other possible harmonization projects, which may become relevant only in the more distant future, serious thought has to be given to whether the WTO is the proper forum for negotiating such projects, in view of its various advantages and disadvantages discussed above and considering whether the required amendments to its legislative process have been made. One must also remember that the WTO, after all, is an organization devoted to international trade, and while it is clearly the case that many types of domestic policies may have some indirect effect on trade and on the comparative advantage of a country, the "trade-relatedness" of some of the newly and not yet proposed harmonization projects is sometimes weak. Serious thought will also have to be given on the desirability of each such harmonization project, weighing its many advantages against its disadvantages, a separate question, which has not been discussed exhaustively in this Article. ${ }^{162}$

162 As was pointed out above, this Article has not attempted to evaluate the normative case for, or against, harmonization of law per se or in connection with each specific project. Rather, we started from the conclusion reached above that harmonization has taken place within the WTO, and that there is a good chance that the organization will continue to play an important role in this field. While we have occasionally described several benefits of possible harmonization projects, this does not amount to an exhaustive normative analysis. Rather, the emphasis of this Article has been on the institutional aspects of harmonization within the WTO in contrast to other organizations. 